Article

\title{
The Regulatory Framework for Market Transparency in Future Power Systems under the Web-of-Cells Concept ${ }^{\dagger}$
}

\author{
Viktorija Bobinaite $^{1, *}$, Marialaura Di Somma ${ }^{2} \mathbb{D}$, Giorgio Graditi $^{2}$ and Irina Oleinikova ${ }^{3}$ \\ 1 Lithuanian Energy Institute, Laboratory for Energy System Research, Breslaujos Street, 3, \\ LT-44403 Kaunas, Lithuania \\ 2 Italian National Agency for New Technologies, Energy and Sustainable Economic Development, Energy \\ Technologies Department-Portici Research Centre, P. E. Fermi, 1, IT-80055 Portici (Naples), Italy; \\ marialaura.disomma@enea.it (M.D.S.); giorgio.graditi@enea.it (G.G.) \\ 3 Department of Electric Power Engineering, Norwegian University of Science and Technology, \\ O.S. Bragstads Plass 2, Electrobygget, NO-7491 Trondheim, Norway; irina.oleinikova@ntnu.no \\ * Correspondence: viktorija.bobinaite@lei.it; Tel.: +370-37-401-956 \\ + Presented at the The 18th IEEE International Conference on Environment and Electrical Engineering (IEEE \\ EEEIC18), Palermo, Italy, 12-15 June 2018.
}

Received: 7 January 2019; Accepted: 1 March 2019; Published: 6 March 2019

check for updates

\begin{abstract}
This paper investigates the regulatory rules of market transparency which could be applied within the wholesale electricity market and market for frequency and voltage control in the Web-of-Cells (WoC) decentralized power control architecture, which has been developed in the ELECTRA Project to respond the challenges and needs of the future power system (2030+). In this decentralized functional architecture for frequency and voltage control, the European Union (EU) power grid is divided into grid control areas, i.e., cells, which are defined as portions of the grid having adequate monitoring infrastructure and local reserves capacity, allowing voltage and balancing (frequency) problems to be solved at cell level, under the responsibility of a Cell System Operator (CSO) (present Distribution System Operator (DSO)/Transmission System Operator (TSO)). In order to foster the practical realization of the WoC-based architecture, the related wholesale electricity market and market for frequency and voltage control are proposed considering the competitive market principles, including transparency. The critical review of the existing EU regulations dealing with this issue suggests respecting the valid provisions on market transparency while tailoring them into the WoC-based architecture. Moreover, in order to take into account the WoC peculiarities, a set of integrations to the current regulatory rules is also proposed, addressing: (1) disclosure of information in respect to attributes of emerging technologies such as renewable energy sources (RES), distributed energy resources (DER), storage; (2) provision of generation and load forecast information; (3) process of procurement of flexibilities; (4) retail market transparency; (5) disclosure of privacy-sensitive household attributes; and (6) disclosure of information on market for frequency and voltage control.
\end{abstract}

Keywords: electricity market transparency; web-of-cells; wholesale electricity market; market for frequency and voltage control; decentralized control architecture; EU regulatory framework

\section{Introduction}

\subsection{Motivation, Focus and Aim of Research}

With the growing share of renewable energy sources (RES) penetration in the power grid at all voltage levels, the increasing electrical load due to the electrification of heating and transport, and the 
active involvement of flexibility resources at distribution level, a number of issues related to reverse power flows, local congestion and voltage problems may arise. In this scenario, the future frequency and voltage control can no longer be effectively managed in a central manner under the responsibility of Transmission System Operators (TSOs). Instead, a radically new approach is required with innovative monitoring systems based on a fully instrumented network, and dynamic autonomous distributed control functions. Indeed, through the current centralised detection and activation paradigm, much detailed local information requires to be collected, aggregated and communicated from all low-voltage and medium-voltage networks to the high voltage TSO to allow it to detect local problems, and establish a secure and optimal reserves activation action using distributed (flexible) resources $[1,2]$. Therefore, a real transition towards a new functional decentralized control architecture is needed also in view of the fundamental transformation of the 2030+ power system. To meet these needs, the ELECTRA Integrated Research Program proposed the Web-of-Cell (WoC) concept $[3,4]$. In this new functional architecture for frequency and voltage control, the European Union (EU) power grid is divided into grid control cells. In detail, the ELECTRA Cell is a portion of the power grid able to maintain an agreed power exchange at its boundaries by using the internal flexibility of any type available from flexible generators/loads and/or storage systems. The total amount of internal flexibility in each cell shall be at least enough to compensate the cell generation and load uncertainties in normal operation. These cells have adequate monitoring infrastructure and local reserves capacity, which allow voltage and cell-balancing problems to be solved at cell level, based on the main concept of solving local problems locally. The real-time reserves activation and dispatching processes are under the responsibility of the Cell System Operator (CSO) assuming responsibility similar to the former TSO responsibility in its control area.

In such a context, the market model and its design required for the practical realization of the proposed architecture of frequency and voltage control is developed as well. Within the WoC concept, this market is intended as an exchange, i.e., the type of organized marketplace where the CSO and the Balance and Voltage Control Service Providers (BSPs) meet to trade balancing and voltage control products in a voluntary, non-discriminatory and transparent way $[5,6]$. From this perspective, in order to correct market failures, market transparency is of high importance for the WoC concept and, therefore, should be addressed at high governmental level.

Based on these premises, the research focuses on concept of market transparency and aims at developing the frameworks for transparency in wholesale electricity market and market for frequency and voltage control designed for the WoC concept, while also tailoring them to the European regulatory rules that are currently imposed for market transparency.

\subsection{Literature Review}

Market transparency generally refers to the amount of information regarding market conditions made public on a timely basis [7]. The relevance of market transparency is reasoned by the effects it can provide, which have been widely investigated in the literature. With reference to transparency issues in the electricity market, in [8,9], it is argued that timely and transparent availability of market data is necessary for a well-functioning electricity market, and market actors need access to market data for operating more effectively, by also developing appropriate plans and business strategies. Moreover, the access to market data should be allowed also to regulators and administrators with the aim of developing or amending market rules, as well as monitoring the market operation for avoiding potential abuses. Subject to transparency, the differences in available information between dominant and smaller market actors are removed, thus, their trust and confidence in trade as well as decision-making increases [10]. Referring to economic theory, scientists [10] observed that transparency is worth attention when developing efficient and liquid markets, as risk and uncertainty are reduced, information asymmetries are removed, better market monitoring is facilitated, the confidence of consumers and their political representatives is improved and the security of power system is ensured. According to [11], wholesale transparency promotes both good functioning and 
competition in the electricity market, by also reflecting positively on the performance of the entire energy sector. Instead, in the absence of transparency, prices can be distorted, and operators holding greater market power enjoy an information advantage which they can use to deter entry and limit fair competition. In [12], an analysis was carried out on how market design influences the bidding behavior in multi-unit procurement auctions, where suppliers have uncertain costs and are also uncertain about the availability of production units, and results showed that the competitiveness of market outcomes improves with enhanced market transparency. In [13], it was found that increased market transparency can facilitate firms' abilities to detect cheating by rivals on a collusive strategy, and in the presence of multiple equilibrium, market transparency may allow firms to coordinate on particular static equilibrium.

In detail, five streams of literature are identified addressing the issues of market transparency in the electricity sector.

The first stream of literature deals with the kind of data and information to be disclosed and the extent to which they should be disclosed. In [14], it is argued that the more information that is disclosed the better. Therefore, fundamental and trading data should be disclosed. In [15], these data are grouped into five categories responding to key activities of the power sector. Therefore, generation, grid, load, price and bidding information are relevant for disclosure. These sources of input and output information are used within the clearing model. The amount of disclosed information and their content depend on electricity market model—pool, bilateral, hybrid—differing in trading, operation and settlement processes. In [10], the publicly disclosed information is given in hierarchical order, where the disclosure of information on technical availability of interconnectors and the TSO network is the most important, whereas the disclosure of information about balancing and generation production is of less relevance. Thanks to the disclosed information, an efficiency and fairness of the market is facilitated, information asymmetries are reduced [15], a level playing field for market participants is created, a market oversight is fostered and an abusive behavior is detected [11]. However, as was observed by [13], disclosure of too much information may harm market functioning by provoking cost inefficient, market power exploiting and collusion establishing behavior. This is in agreement with observations made by [10]. In [10], it was argued that due to considerable market transparency, effective competition may be disturbed due to the reduction in incentives for innovation as private data are disclosed, the decrease in incentives to develop liquid market, and the presence of high information infrastructure costs. Instead, only relevant information for rational economic behavior of market actors is necessary to be disclosed, if this improves economic decisions. Therefore, the access to price information is essential as it is needed for temporal supply and demand decision making, whereas intertemporal decisions-maintenance, repair, upgrading of power plants (PPs), investment, entry into and exist from the market-are taken considering current and historical prices [13]. The deep understanding of underlying processes of price formation and disclosure of related information is requested for making price forecasts, which are used to take decisions when there is no price information [13].

The second stream deals with the issue of data quality and other requirements set for data and information. The European Regulation [16] establishes the key requirements for data and information disclosure. In order to improve market transparency, the actors are requested to be provided with timely data. These data should be regularly updated and provided for different timeframes. The data should be up to date, easily accessible, downloadable and available for at least five years. This is in agreement with [8], who identified the timeliness and availability of market data, their accessibility, and confidence promoting, as key requirements for data. According to [17], high data quality is an essential condition of data analysis and mining. With the purpose of extracting knowledge from data to support decision-making, the data quality should be ensured as (big) electricity data impact on the accuracy and effectiveness of electric power system management and the safety and reliability of the power system operation.

The third stream of literature discusses electricity sector-related transparency platforms, which are recognized as instruments of transparency as they serve to publish the most relevant power system 
data in a single place [18]. In [18], it was found that the transparency platform of the European Network of Transmission System Operators for Electricity (ENTSO-E) is a very ambitious project. However, it suffers from a number of shortcomings, such as lack of data quality and attractiveness for usability [19]. In [20], it was found that the Smart Meter Analytics Scaled by Hadoop (SMASH) provides industry with a competitive and easily operable platform to manage big energy data, while also supporting data-intensive decision making. According to [21], the Open Power System Data Platform (OPSDP) assures the efficiency and quality benefits of centralised data provision, as it provides gains to energy system analysis by raising the efficiency of data pre-processing, by providing a method for making data pre-processing for energy system modelling traceable, flexible and reproducible, and improving the quality of original data published by data providers.

The fourth stream of literature tackles the issue of the electricity Information Disclosure Mechanism (IDM). Electricity IDM is recognized as one of the instruments for improved market transparency, as it provides open and easy access to relevant information [22]. In [23], it was found that there is a need for reliable information and market transparency, as consumers want to compare electricity products with reference to price, generation sources, and environmental and contractual attributes. Therefore, requirements on disclosure to consumers-in a comprehensible and clearly comparable manner [23] — of the fuel mix used for the electricity production and the associated $\mathrm{CO}_{2}$ emissions, and production of radioactive waste related to power generation [24] are essential. The importance of the electricity IDM is supported by its positive impacts on improved sustainability of energy systems as they move towards the use of RES [25]. Moreover, information disclosure, as a procedural policy measure, helps to increase public awareness, political legitimacy and adoption of substantive policy [25]. In [23], it was found that competition may increase thanks to improved consumer confidence in its ability to choose among electricity offerings under the critical information disclosure condition. Moreover, electricity disclosure is a key element for the consumer protection and it is also a beneficial educational tool in regulated electricity markets [23].

The fifth stream of literature copes with privacy preservation when sharing and disclosing data, especially residential energy usage data. Following the trend of information technologies integration into the power grids at the expense of reduced privacy, the issue is of high importance in smart grids. Various methods and techniques are proposed for privacy preservation [26]. In [27], a sharing method of electricity usage-that is the self-organizing map-was proposed for that purpose. This allows power suppliers sharing a node map of electricity usage and raw data to be captured from smart meters. In [28], the redaction of data and the addition of artificial noise were considered as two data pre-processing techniques that customers could apply before data sharing. In [29], the privacy preserving reward scheme providing privacy-preserving mechanism to reward users for the electricity data they submit to a utility provider was suggested.

The literature review above shows that thus far the issue of market transparency is to a certain extent analysed in the context of a centralized control of power system and electricity market models mostly supplied with traditional energy sources. Following the expected developments in 2030+ power system and the compelling need to consider a new approach towards a decentralized control of power system equipped with RES, distributed energy resources (DER), electric vehicles (EVs) and storage technologies, which are mainly connected to low- and medium-voltage grids, there is room for market transparency investigations. In addition, comprehensive analyses focusing on the issue of electricity market transparency from the regulatory point of view are difficult to find in the literature.

\subsection{Goals and Contributions}

In order to fulfil the gaps identified above, the contribution of this paper is to analyse and demonstrate the concept of market transparency for the WoC control architecture and the requested market model and its design, through the perspective of the EU regulatory framework and the legislation point of view. In order to foster the practical realization of the WoC control architecture, the related wholesale electricity market and market for frequency and voltage control are proposed 
considering the competitive market principles, including transparency. The main goal is to provide a set of potential solutions to address this issue, which are based on adapting and tailoring the current regulatory scopes on wholesale electricity market transparency for the WoC concept and proposing supplemented ones that reflect the peculiarities of the WoC. In detail, the review of the existing European Directive and Regulations suggests respecting valid provisions on wholesale electricity market transparency while tailoring them into the WoC concept. For addressing the transparency issue in the wholesale electricity market for the WoC concept, the main proposals developed are related to: (1) imposing actors with responsibilities in relation to market transparency; (2) applying the Information Exchange Mechanism (IEM) to improve access to power grids for cross-cell exchanges in electricity; (3) using a multi-dimensional wholesale electricity market transparency model preventing market abuse and fostering open and fair competition; and (4) employing the method of data and information submission and publication agreed at EU level. With reference to the market for frequency and voltage control for the $\mathrm{WoC}$, it is proposed for the transparency issue to be solved by addressing: (1) the minimum data set and its availability for Merit Order Collection (MOC) and the Merit Order Decision (MOD) making within the WoC concept; (2) roles for the actors regarding data and information collection, provision, aggregation, use and publishing; (3) data placement; and (4) data and information publication. Moreover, the market transparency issue within the WoC concept is tackled through the supplemented solutions that are beyond the existing European regulatory rules, including: (1) disclosure of information in respect to attributes of intermittent RES, DER, EVs and storage technologies and virtual power plants (VPPs); (2) provision of generation and load forecast information; (3) process of procurement of flexibilities; (4) retail market transparency as an integral part of market transparency; (5) disclosure of privacy-sensitive household attributes; (6) disclosure of information about the market for frequency and voltage control.

The rest of the paper is organized as follows. Section 2 briefly introduces the research method adopted for developing the regulatory framework for market transparency under the WoC concept. Section 3 presents the detailed overview of the European wholesale electricity market transparency framework. Section 4 presents the wholesale electricity market structure for the WoC control architecture. Sections 5 and 6 presents the frameworks for transparency in wholesale electricity market and in the market for frequency and voltage control, respectively, supporting the WoC concept. Section 7 discusses the possible amendments in current regulation for tailoring the frameworks of market transparency in the WoC. Finally, in Section 8, the conclusions are drawn.

\section{Research Method}

The regulatory framework for market transparency under the WoC concept is developed considering the approach of the sequential performance of tasks on the strength of the task-specific research methods, as shown in Figure 1.

The research was carried out based on the five formulated tasks- that are the titles of constructs in Figure 1-as described below:

- Firstly, a critical literature review was done by considering both scientific literature and current EU legislation dealing with the issue of electricity market transparency. This activity allowed identifying the key elements and measures of electricity market transparency as well as the scope of electricity market transparency regulation at EU level.

- Then, peculiarities of the research subjects, which are the WoC frequency and voltage control architecture and the related market design, were analysed based on the ELECTRA project outcomes.

- Furthermore, the market transparency framework for the WoC concept was developed based on the method of systematic review of literature and EU legislation. In particular, this took into consideration the methodological guidelines proposed in [10]. Here, a list of issues and questions about how to translate the market transparency considerations into the operational guidance are provided. Finally, the proposed frameworks for market transparency were tailored to the 
European-level regulatory rules applying the methods of systematic review of the ELECTRA project outcomes and reasoning.

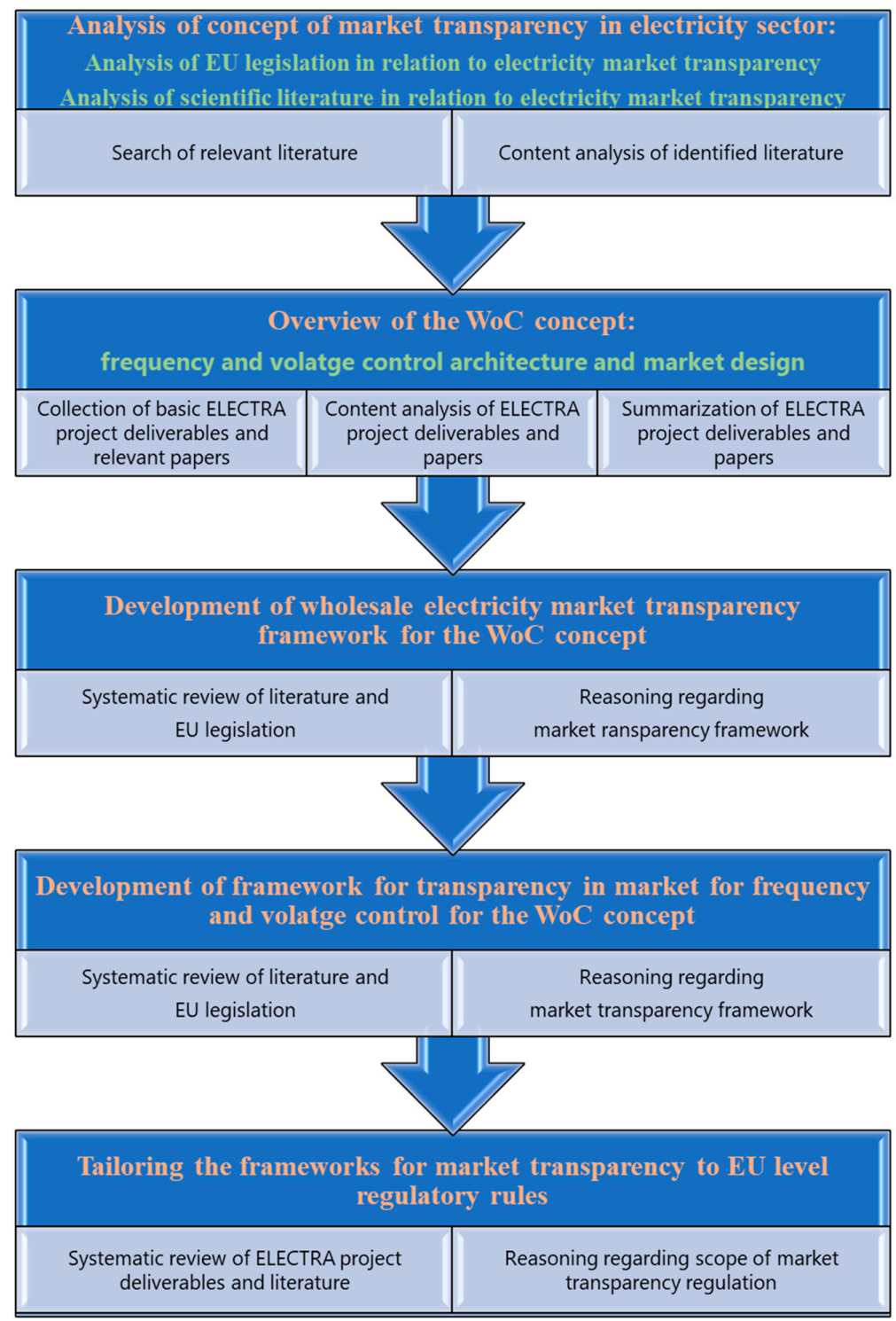

Figure 1. Logical scheme of research performance and related research methods.

\section{European Regulatory Framework for Wholesale Electricity Market Transparency}

The issue of wholesale electricity market transparency in Europe is tackled through the following legislation:

- Directive 2009/72/EC on common rules for the internal market in electricity [24];

- Regulation No 714/2009 on conditions for access to the network for cross-border exchanges in electricity [30];

- Regulation No 713/2009 on the establishment of the agency for cooperation of energy regulators [31];

- Regulation No 1227/2011 on wholesale energy market integrity and transparency [32];

- Regulation No 543/2013 on submission and publication of data in electricity markets [16].

In the following, a short description of each piece of legislation in relation to market transparency is given. 


\subsection{Directive 2009/72/EC on Common Rules for the Internal Market in Electricity}

The primary purpose of the directive [24] is to establish common rules for the generation, transmission, distribution, supply of electricity and consumer protection, with the aim to improve and integrate competitive electricity markets in Europe. Issues of the wholesale and retail electricity markets transparency remain important within the directive. In detail, increased transparency of retail markets is a new and strongly focused topic whereas the transparency of wholesale electricity market is covered only fragmentally within the directive. However, a general and high-level framework for wholesale electricity market transparency is established. It focuses on the actors and their roles in relation to a transparent wholesale electricity market. Within the framework, European Commission (EC), the Member States (MS), the National Regulatory Authorities (NRAs), TSOs and Distribution System Operators (DSOs) and undertakings are provided with the mandatory responsibilities in the area of market transparency. With the purpose to improve transparency, the EC has the obligation to monitor and review the application of the directive and submit an overall progress report to the European Parliament and the Council (EP\&C). The MS are provided with the duties regarding transparency of accounts. The NRAs are set with a duty of monitoring the level of transparency, providing information on the market to permit the EC to exercise its role of observing and monitoring the internal market in electricity. The TSOs are responsible for providing to the operator of any other system with which its system is interconnected the needed information to ensure a secure and efficient operation. The DSOs are responsible for providing system users with the information they need for efficient access to, including use of, the system. Finally, transparency in electricity generation sector is also addressed in provisions regarding authorization procedure for new generating capacity and tendering for new capacities. Provision is also included on record keeping setting the requirement for the undertakings to keep relevant data relating to all transactions for at least five years.

\subsection{Regulation No 714/2009 on Conditions for Access to the Network for Cross-Border Exchanges in Electricity}

With its primary purpose to create a well-functioning wholesale electricity market with a highly secure supply of electricity, and enhance competition in the internal market by setting straightforward rules for cross-border exchanges in electricity, the regulation [30] addresses the issue of wholesale electricity market transparency as well, through establishing a high-level Information Exchange Mechanism (IEM). The IEM is developed within the scope of access to the network for cross-border exchanges in electricity. The established IEM consists of several elements, which are summarized in Figure 2 and discussed below.

The EC, the ENTSO-E, the Agency for the Cooperation of Energy Regulators (ACER), the NRAs, the TSOs, and supply and generation undertakings represent the main actors taking part in the IEM. They are involved in the exchange of data and information in the areas of certification of TSOs, establishment of network codes, preparation of 10-year network development plans, solving issues of congestion management, application of inter-TSO compensation mechanism, use of new direct current interconnectors, and management and allocation of available transmission capacity of interconnections between the national systems. The IEM proposes that consultations and monitoring are relevant methods, and that annual reports, outlooks, network codes, working programme, recommendations, reasoned opinions, regional investment plans or guidelines are important channels of the IEM. Thus far, the actors, if obliged, exchange among themselves "all relevant and necessary information". From this perspective, the IEM is not complete, and thus issues of provision and disclosure of confidential or sensitive data and information arise. These issues are fragmentally covered within the IEM. However, the IEM strictly highlights the types of data and information to be provided by TSOs in their area of management, and allocation of available transmission capacity of interconnections between national systems. Within this area, the TSOs take responsibilities against transparency, in the sense that they publish ex ante and ex post data related to network availability, network access, network use, data concerning cross-border trade, generation and demand forecasts, as well as data for cross-border balancing of the market. The TSOs contribute to transparency by providing the market with 
descriptions on the congestion management method, procedures in use for the congestion management and capacity-allocation, a scheme for calculation of the interconnection capacity, operational and planning security standards, as well as specifications of products offered. All this information is especially relevant for the market actors when negotiating all types of transactions in wholesale electricity products. The actors of the IEM exchange information and data on regular basis, which can be a single one-time information provision or periodicity of information exchange, which is not regulated within the IEM. In such a perspective, with the purpose to improve transparency, setting the periodicity of data and information provision is of key importance, and this is valid also for the implementation of the primary purpose of this regulation. Therefore, the TSOs are obliged to provide relevant data concerning cross-border trade daily, weekly, monthly and annually. The ENTSO-E supplies annually a working programme, report, generation adequacy outlooks, whereas every two years it provides a 10-year network development plan. Within the IEM, the actors (mainly, the EC) are left with the right to determine a time-limit within which information should be provided, and set penalties for incorrect, incomplete or misleading information provision. The IEM does not regulate the size of penalties, but determines three criteria (effective, proportionate and dissuasive) based on which penalties should be set by the MS. The regulation gives the responsibility to the EC to impose fines of a certain size (not exceeding $1 \%$ of turnover in the preceding business year).

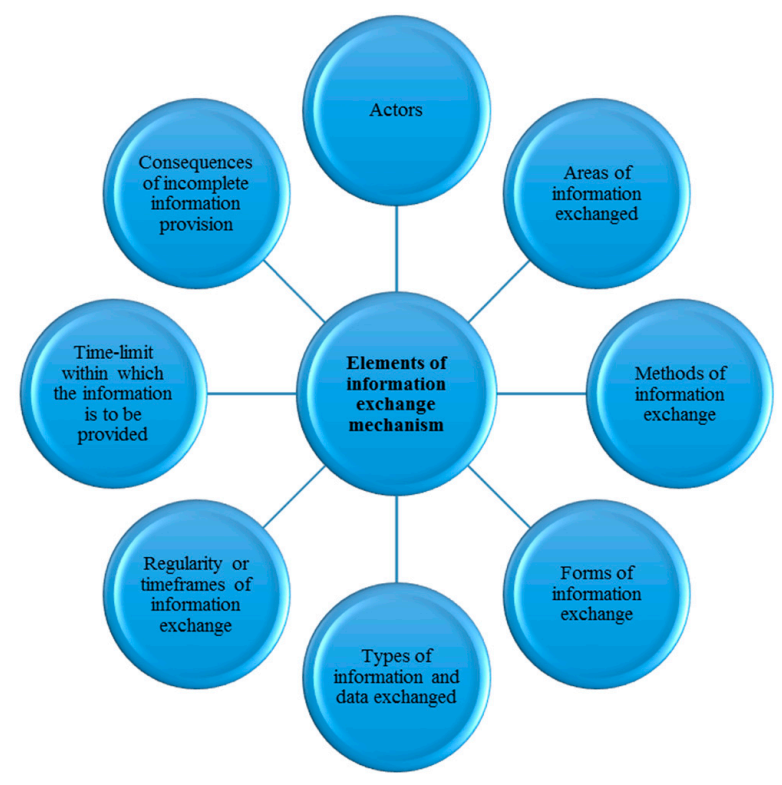

Figure 2. Elements of information exchange mechanism developed for improved access to the network for cross-border exchanges in electricity [30].

\subsection{Regulation No 713/2009 on the Establishment of the Agency for Cooperation of Energy Regulators}

The regulation [31] aims at establishment of the ACER to assist the NRAs in performing the regulatory tasks prescribed to them and coordinating their actions at European level. The regulation focuses on the roles and responsibilities of the ACER in the internal electricity market. For the purpose to improve transparency in internal electricity market, the ACER is obliged to:

- issue opinions and recommendations addressed to the ENTSO-E, the TSOs, the NRAs, the EP\&C, and take decisions on the terms and conditions when accessing electricity infrastructure which connects at least several MS;

- monitor the functioning of the internal market, and implement the 10-year network development plans and regional cooperation of the TSOs.

Moreover, on an annual basis, the ACER takes responsibility for publishing a report on its findings publicly. 
Within the ACER, several departments are established to assure transparency in the internal market. The Market Integrity and Transparency Department is responsible for general policy matters addressed within the Regulation No 1227/2011 on wholesale energy market integrity and transparency (REMIT) [32], market data reporting, data quality, data sharing, business intelligence tools and market data management tasks under the REMIT [33]. The Market Surveillance and Conduct Department monitors and assesses market data on irregular cases, informs the NRAs about suspected market abuse cases and provides advices to NRAs regarding the concept of market abuse [33].

\subsection{Regulation No 1227/2011 on Wholesale Energy Market Integrity and Transparency}

With the goal to prevent market abuse and foster open and fair competition in wholesale energy markets, the regulation [32] develops a multidimensional wholesale energy market transparency model. The model consists of several dimensions addressing the key transparency-related issues that are regulated in wholesale energy markets, which are:

- prohibition of use of inside information. Within the dimension, the activities where the use of inside information is prohibited, are established, and the actors who are not allowed to exercise these activities are identified. Moreover, exemptions to the rules are set. Therefore, persons being the highest in the managerial hierarchy of undertaking, holding capital in it, or accessing information through the exercises they do in that undertaking or through the criminal activity, are prohibited from using themselves or disclosing to any other person inside information for the purpose to acquire wholesale energy products to which that information is related. Recommendations provided to other persons to acquire wholesale energy products based on inside information are also prohibited. However, this is not applied to the TSOs when purchasing electricity for the purpose of ensuring safe and secure operation of the power system. Within the dimension, several other cases are identified where prohibition to use of inside information is not applied. In particular, market actors performing under the national emergency rules, and electricity producers entering into transactions, in cases which would result in them not being able to meet contractual obligations or not ensuring safe and secure operation of the power system, could use inside information when acquiring wholesale energy products.

- publication of inside information. Within the dimension, the market actors have an obligation to disclose inside information they possess, publicly and on time. This includes information about capacity and its use, consumption and transmission of electricity.

- prohibition of market manipulation. Within the dimension, the attitude towards manipulations is expressed. In particular, the participation of market actors in manipulations on wholesale energy markets at any form is prohibited.

- market monitoring. With the purpose of finding out and preventing trading cases based on the use of inside information and market manipulation, the dimension obliges the ACER to monitor trading activity in wholesale electricity products.

- data collection. Within the dimension, data and information providers and receivers are identified. Moreover, the type of information that should be provided and its detail level is set. Therefore, trade reporting systems, market actors, and organized markets are relevant data and information providers to the ACER, and the NRAs. They have an obligation to provide information about wholesale electricity products bought or sold, price and quantity agreed, date and time of execution, etc.

- registration of market actors. Within the dimension, the requirement is set that market actors making transactions, which will be reported to the ACER, have to be registered with the NRAs.

- data protection operational reliability. Within the dimension, the EU-level regulations protecting individuals with regards to the processing of personal data are identified. The ACER, the NRAs and other data receivers are obliged to ensure confidentiality, integrity and protection of information received. Information received are required to be published with the aim of improving the transparency of wholesale energy markets. 
- implementation of prohibitions against market abuse. Within the dimension, the NRAs have the investigatory and enforcement power necessary for implementation of prohibitions against the market abuse. Therefore, the NRAs have specific rights in relation to access to information.

- cooperation at European and national levels. Within the dimension, the ACER aims at ensuring the NRAs carry out their tasks in a coordinated and consistent way.

- professional secrecy. Within the dimension, the confidential information received, exchanged or transmitted are subject to the conditions of professional secrecy.

\subsection{Regulation No 543/2013 on Submission and Publication of Data in Electricity Markets}

The regulation [16] approves the mechanism for relevant data submission and publication, and addresses the issue of information and data importance and availability for market actors to take efficient production, consumption and trading decisions under the conditions of deep market integration and rapid use of RES for electricity production. The information and data submitted and published are divided into four categories, including load information, generation information, grid information and balancing information. The list of the minimum set of data related to generation, transportation and consumption of electricity to be made available to market actors is formed. In particular, the regulation pays attention to the submission and publication of data and information related to total load, unavailability of consumption units and transmission infrastructure, estimation, offer and use of cross-zonal capacities, congestion management measures, actual and forecasted generation, unavailability of generation, and information on balancing. Within the regulation, the TSOs facilitate the collection, verification and processing of data and the ENTSO-E makes those data available to the public through a free central information transparency platform, which is established with the aim to evenly distribute relevant market information among the various market actors. Moreover, in order to better use the sources of transparency, the ENTSO-E receives information for publication through the third parties such as power exchanges and transparency platforms as well.

\subsection{Summary of European Wholesale Electricity Market Transparency Framework}

The European wholesale electricity market is under transparency requirements. They are relevant measures to ensure the creation of a common electricity-market [34] that is well-functioning [8,9]. The wholesale electricity market transparency framework is well-developed and disclosed in a clear manner through the European legislation. These are directive [24] and several interlinked regulations [16,30-32]. The aforementioned EU legislation determines the dispersed scope of regulation, by establishing the high-level framework for wholesale electricity market transparency, the responsibilities to ACER, the IEM to improve access to network for cross-border exchanges in electricity, the multidimensional wholesale electricity market transparency model preventing market abuse and fostering open and fair competition in wholesale electricity market, as well as the framework for data and information submission and publication. The dispersed scope means that market transparency requirements are set in different EU legal acts and are prepared for particular areas requiring transparency. In particular, EU legislation regulates the activities of electricity market actors such that they act in a transparent way, the set of data and information that should be publicly published is based on established rules, and there are measures preventing market abuse and facilitating competition. The regulations respond issues of wholesale electricity market, including issues of market transparency and proposes solutions from the here and now to the short and medium terms. However, European power sector will undergo significant structural developments in long-term, requiring new approaches towards power system operation, functioning of internal market, regulation of power system and market. From this perspective, the regulatory rules imposed on the existing European wholesale electricity market transparency framework should be updated to respond to the changes. Therefore, in the following, the expected developments are discussed and required regulatory amendments are proposed. 


\section{Description of the Web-of-Cells (WoC) Architecture for Frequency and Voltage Control and the Related Wholesale Electricity Market}

\subsection{Description of the WoC Concept}

The massive availability of flexibility energy resources mainly connected at distribution level that has been foreseen leads to the idea that decentralized control aiming to solve local problems locally will best address the fundamental changes in the future power systems. Based on this concept, the WoC concept proposes a new architecture for frequency and voltage control for future power systems. In such a framework, the European power grid is divided into grid control areas, i.e., the cells. A cell can be defined as a portion of power grid able to maintain an agreed power exchange at its boundaries by using the internal flexibility of any type available from flexible generators/loads and/or storage systems. The total amount of internal flexibility in each cell shall be at least enough to compensate the cell generation and load uncertainties in normal operation. Therefore, the cells, based on proper monitoring infrastructures and local reserve capacity, are able to solve voltage and cell-balancing (frequency) problems at cell level, thereby putting in practice the concept of solving local problems locally. Each cell is under the responsibility of a CSO (present DSO/TSO) that supervises its operation, and, if needed, is able to override it. This control architecture for frequency and voltage radically changes the current paradigm involving a central TSO who is responsible for detecting local problems and taking consequent actions.

\subsection{High-Level Functional Architecture of Frequency and Voltage Control}

High-level functional architecture for frequency and voltage control is presented in Figure 3.

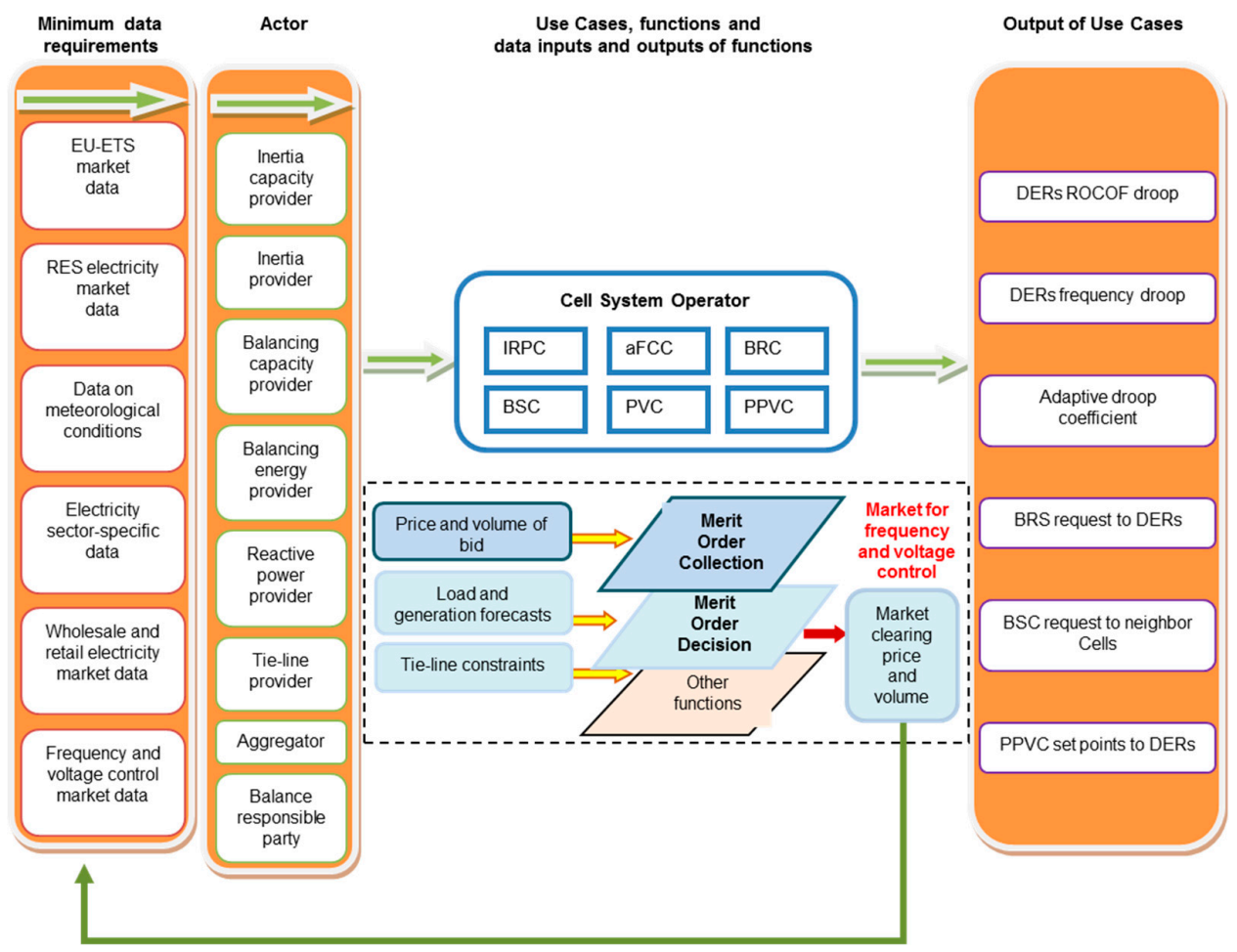

Figure 3. High-level architecture for frequency and voltage control under the Web-of-Cells (WoC) concept [35].

The architecture consists of six use cases (UCs), i.e., Inertia Response Power Control (IRPC), Adaptive Frequency Containment Control (aFCC), Balance Restoration Control (BRC), Balance Steering Control (BSC), Primary Voltage Control (PVC) and Post-Primary Voltage Control (PPVC) functionalities, which are managed/operated by the CSO. 
Each functionality is implemented through the number of UC specific functions, considered as black-boxes in Figure 3, since the specific control schemes are out of the scope of this paper. Conversely, the MOC and the MOD functions (to be discussed later in Section 6) are important, since they can be implemented within the architecture only if the market for frequency and voltage control, whose efficiency and good functioning is covered by the transparency requirement, is established. Both these functions are served by various actors. The BSPs for inertia capacity, inertia, balancing capacity, balancing energy and reactive power, the providers of tie-line, the aggregators, and the Balance Responsible Parties (BRPs) are found to be a constituent part of the architecture, as they are important for the market functioning. The first five types of the actors either on their own or through the aggregation participate in the MOC function implementation. They bid the market and establish an initial Merit Order list for the specific UC. When bidding in the market, they use different resources, including gas-based thermal PP, RES-based (wind, solar, hydro) PP, demand response (DR) technologies (industrial loads, EVs, household appliances) and storage technologies (batteries and pump hydro) that are connected to all voltage grid levels. The tie-line providers supply the CSOs with data and information about constraints in the tie-line. The BRPs-either these are generators, consumers or traders-inform the CSOs about their balance positions. In order to avoid discrimination between market actors and treat them equally, also producers of electricity from RES and high-efficiency cogeneration have balance responsibility. The BRPs provide the CSO with load/generation forecasts (only large-scale BRPs), whereas the aggregators send to the CSO load/generation forecasts of the remaining BRPs. Altogether they contribute to the implementation of the MOD function of the specific UC.

The functions are supplied with various data (to be discussed later in Section 6). They are derived and decided by using secondary data, including data of the electricity sector, wholesale electricity market, market for frequency and voltage control and other. This is done for the purpose to justify bidding, tie-line constraints-related and forecasting decisions.

The final output of actors' participation in the implementation of the functions and their interaction within the UCs are the distributed energy resources' rate of change of frequency (DERs RoCoF) droop, DERs frequency droop, etc., which are the parameters of the architecture of the frequency and voltage control for future power systems under the WoC concept.

\subsection{Wholesale Electricity Market Structure for the WoC}

Within the WoC concept, electricity is traded in different wholesale electricity markets as shown Figure 4.

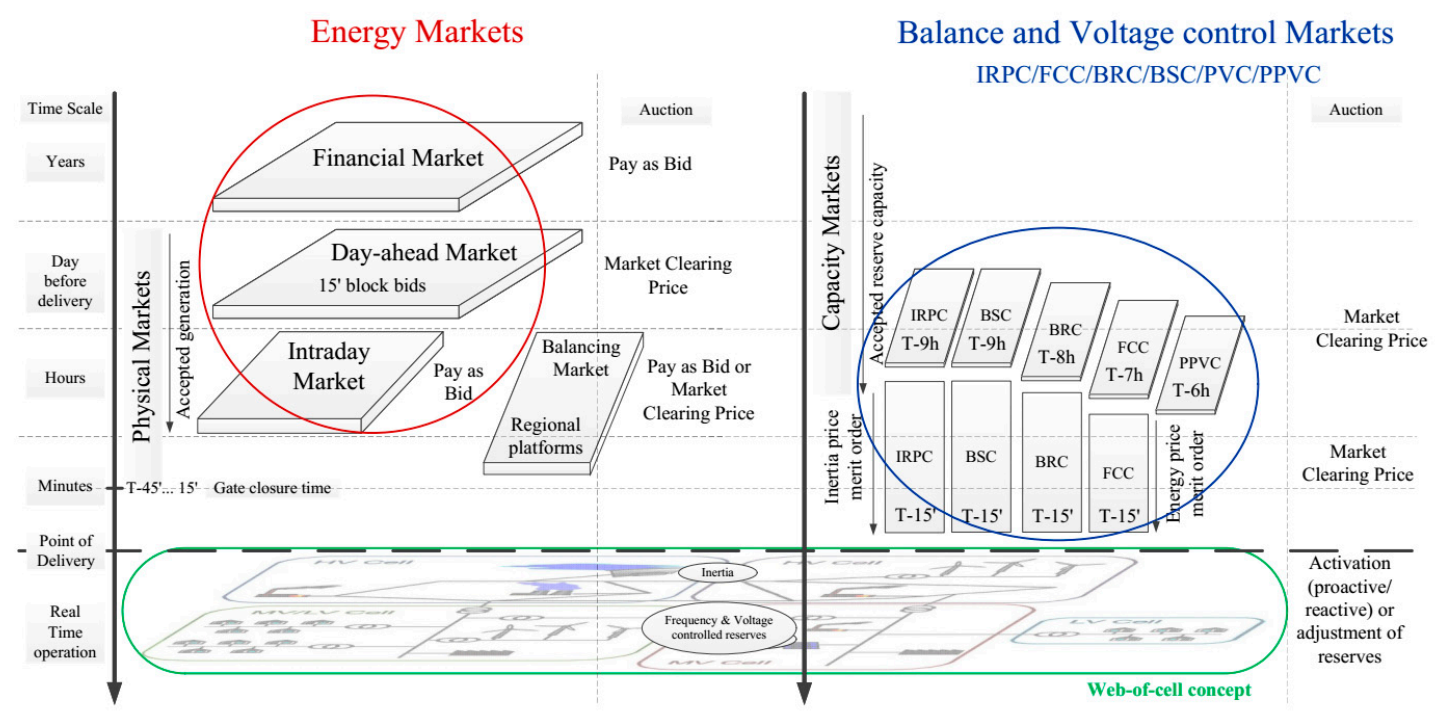

Figure 4. General structure of the electricity market within the WoC concept [5]. 
The Financial market functions for the purposes of electricity price hedging and risk management and it is established at WoC level. Here, future and forward contracts are agreed. The contracts are standardized and bilateral agreements are made by market actors and traded in the power exchange and over-the-counter (OTC), respectively. The market actors trade in short-term (up to one year) and long-term (duration is more than one year) contracts. The price of the contracts is determined considering the prices in the day-ahead market. Electricity producers and aggregators choose the contracts to hedge against electricity price decreases in future, whereas electricity consumers either themselves or through their representatives (including suppliers) purchase them to secure their future electricity consumption volumes and to hedge against price decreases.

The Day-Ahead market (DA market) is established at WoC level to trade in electricity one day before its actual delivery. Therefore, in this market, the related actors submit price proposals for transactions taking place the next day. The WoC concept respects the Scandinavian practice of DA market functioning. Here, electricity is traded in a marketplace known as a power exchange. Electricity and transmission capacity are traded together. Therefore, subject to congestion, different price zones are established. The market clearing approach is applied to determine market clearing price and volume. The market time unit is $15 \mathrm{~min}$.

The Intra-Day market (ID market) is also established at WoC level to trade in electricity every day until one hour before its delivery. The ID market enables its actors to correct the imbalances they suffer after DA market closure. The imbalances happen due to poor wind forecasts, unexpected power plant outages, etc. In the ID market, electricity is traded on the power exchange but meaning orders provided by the market actors are continuously cleared based on the principle of first-come, first-served. Therefore, many prices are established during an hour, thus, an organized OTC (oOTC) market operates. The ID market is very important in the WoC concept since a large amount of intermittent RES electricity (which is poorly predictable) is supplied to the grid and must be balanced.

The Energy balancing market is established at the cell level. It aims at correcting possible power system imbalances before real-time (RT) but after ID market closure. This market is operated by the CSOs who have obligations to balance their cells. The energy balancing market opens three hours after the DA market closes (i.e., 15:00 CET), collects bids from the BSPs and establishes the Merit Order list of UCs $15 \mathrm{~min}$. before the production hour, as shown in Figure 5.

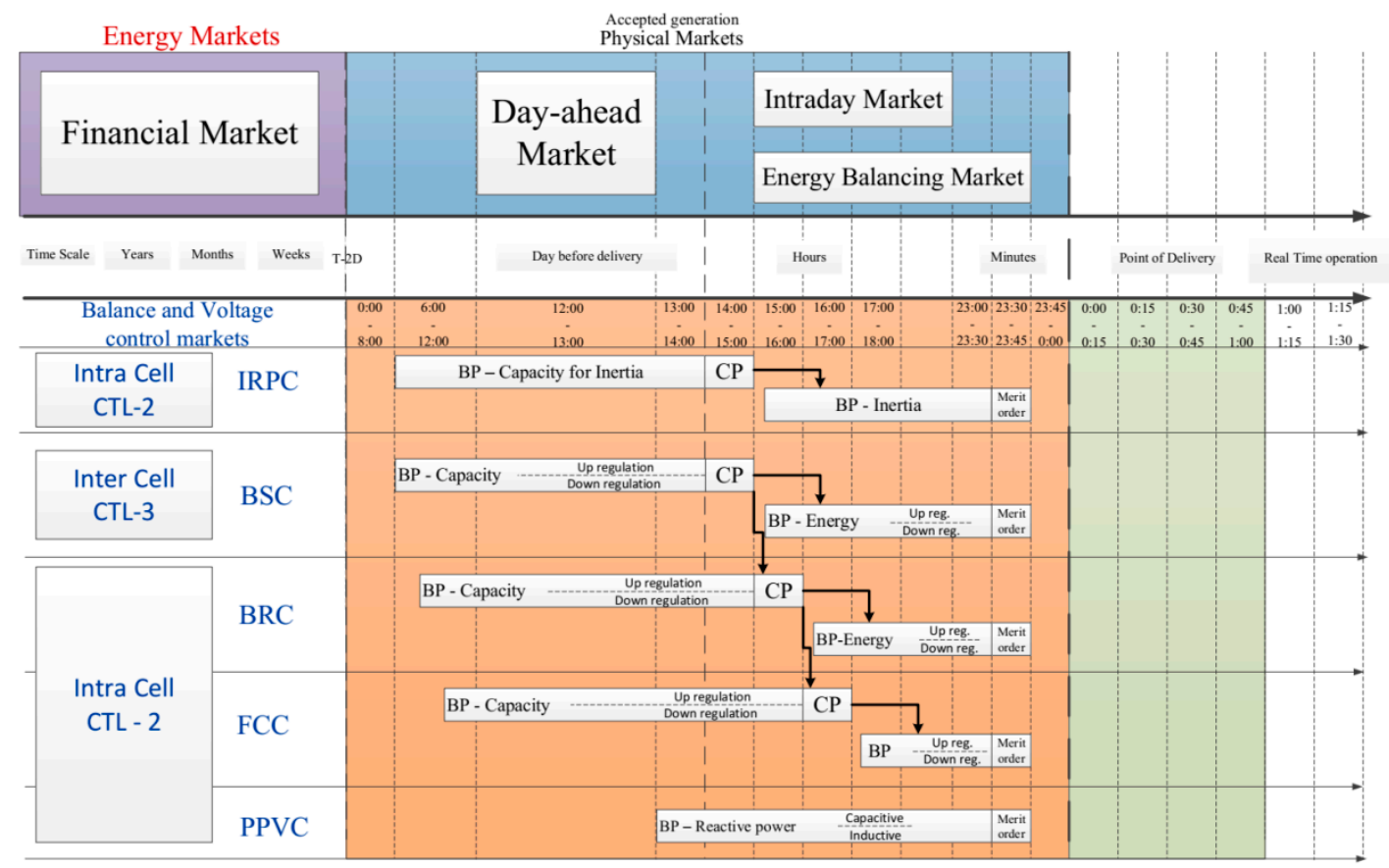

Figure 5. Market sequence organization under the WoC concept [35]. 
The energy balancing market is a constituent part of the market for frequency and voltage control, which is developed for the functioning of the WoC control architecture. In the market for frequency and voltage control, inertia capacity, inertia, balancing capacity and balancing energy for upward and downward regulation, as well as reactive power, are traded to balance and control the cell and settlements are carried out. The CSOs, the BSPs, the BRPs and the NRA are the key actors taking part in the market processes of procurement, settlement and supervision.

On the procurement side, an organized marketplace is established. Within it, the CSOs and the BSPs trade in the UCs in an auction-based exchange on voluntary basis and considering competitive market principles. The exchange as a pro-market instrument is selected due to its expected benefits in terms of high liquidity and market transparency [34]. The trade in UCs is organized every $15 \mathrm{~min}$. In the market, the CSOs purchase UCs from the BSPs. Trade is organized such that inertia capacity and balancing capacity is initially traded. Then, within the volumes of capacities won, inertia and balancing energy bids are submitted. Therefore, the BSPs are paid for both availability and utilization of inertia capacity, and balancing capacity. In the market, the price and volume of UCs' products are set considering the market clearing approach. Subject to it, the CSOs purchase a certain volume of UC product for a particular market time unit at a single price. In the market, only short-term (15 min, $30 \mathrm{~min}$ and $60 \mathrm{~min}$ ) standard UCs are traded. The IRPC, aFCC, BSC and PPVC are traded at the intra-cell level, meaning that no trade in the UCs is available between the cells. Here, the CSO is thus a single buyer of the UCs' products. Therefore, a monopolistic market structure is developed. Conversely, the BRC is traded at the inter-cell level, meaning that it is traded by many BSPs and CSOs from different cells. Thus, a competitive market structure is developed [36].

At the imbalance settlement side, settlements are carried out. Here, the CSOs and the BRPs decide on production, trade and consumption imbalances, imbalance price and imbalance cost, its distribution and cost recovery [36].

The NRA is set up to perform its market supervision role in the market for frequency and voltage control [36].

\section{Framework for Transparency in Wholesale Electricity Market Supporting the WoC Concept}

The framework for transparency in the wholesale electricity market facilitating a well-functioning WoC concept is developed within the European legislation discussed in Section 3. In general, it respects the scopes of the directive [24] and regulations [16,30-32] related to wholesale electricity market transparency in Europe, and assumes that they are key for the development of a well-functioning, efficient and transparent wholesale electricity market under the WoC concept.

Figure 6 presents the high-level framework of wholesale electricity market transparency for the WoC concept by emphasizing the key actors and directions of data and information flows.

The wholesale electricity market transparency framework for the WoC concept is developed considering both horizontal and vertical approaches towards transparency. Based on these approaches, the actors exchange ex ante and ex post data and information among themselves, and provide data and information to higher-level networking institutions (the ENTSO-E and the ACER), which themselves are responsible for the data and information provision to the highest-level institutions, such as the EC. Within this framework, many actors have responsibilities regarding activities' implementation for which they can improve transparency in the wholesale electricity market. In detail, the EC observes, monitors and reviews the adaptation of the directive [24] in relation to the implementation of an internal market in electricity and reports the EP\&C on findings and progress made. The ACER collects and processes data and information in order to monitor the functioning of wholesale electricity market and assesses the irregular cases at the WoC level. Moreover, in case of disagreement between the cells, which are regulated by different NRAs, it takes decisions on the terms and conditions related to accessing the grid which connects these cells. However, if cells are within the regulation area of the particular NRA, the NRA takes the related decisions. In addition, the NRA collects data and information for the purpose of monitoring the level of transparency in the cells which are in its 
regulation area and ensures that primary owners of data, the CSOs comply with their obligation regarding submission and publication of data in electricity markets. The CSOs, who take care of highto low-voltage grids, exchange data and information with the CSOs with whom their grid is connected. This is done for the purpose to ensure the secure and efficient operation. The CSOs collect, verify, process and exchange daily, weekly, monthly and annually ex ante and ex post data related to the grid availability, access to the grid, use of grid, data concerning inter-cell trade in electricity, generation and demand forecasts, data about market for balancing and voltage control; whereas the ENTSO-E makes these data available to the public on a regular manner through the established information transparency platform. The market actors being the primary owners of data and located within the area of a particular CSO, provide that CSO with all relevant information. They also use, disclose and publish inside information and information related to capacity and use of facilities for production, storage, consumption or distribution, transmission of electricity, provide records on market transactions, and keep records of all transactions for a determined time period.

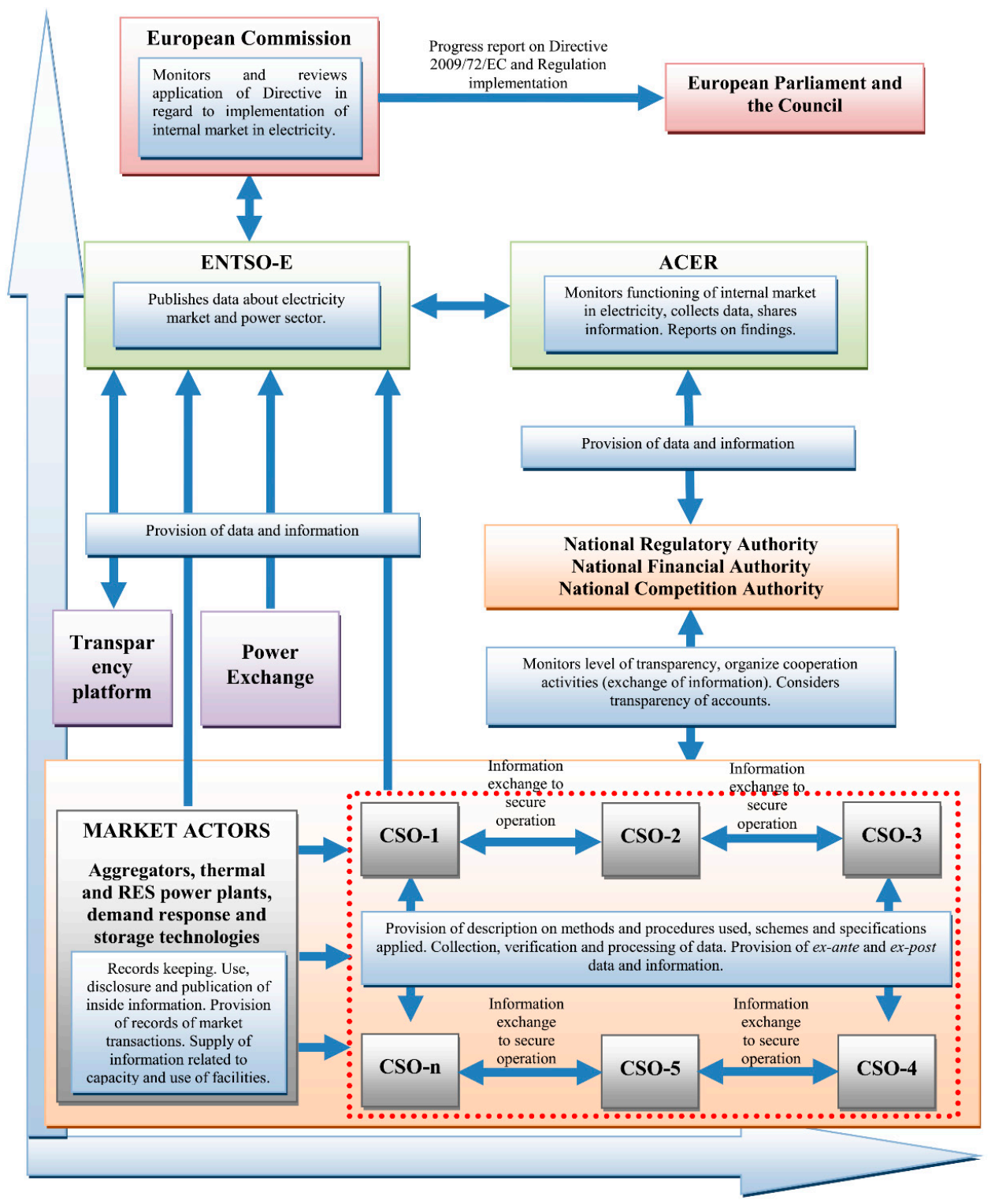

Figure 6. Wholesale electricity market transparency framework under the WoC concept [36].

In the long term, when intermittent RES, DER, EVs and storage technologies are used at scale, the information disclosure mechanisms need to be updated to reflect these changes. Therefore, responding 
to these challenges, some improvements in wholesale electricity market transparency framework are foreseen. New actors (VPPs, industrial and residential DR technologies, etc.) enter the power sector and market, and they are set with market transparency requirements too. The application scope of market transparency requirements is expanded to actors whose PPs and devices are connected to all voltage levels. Transactions in the market are plentiful. In agreement with [15], information regarding the eco-label of an electricity producer is requested because actors express their willingness to pay for electricity from RES. Information about VPPs, storage and DR technologies are integrated too. Information is updated more frequently than presently because of quick changes in electricity supply [15]. Therefore, it is expected that the framework for wholesale electricity market transparency functions according to the condition of a large-volume, high-velocity and big-diversity of data and information.

\section{Framework for Transparency in Market for Frequency and Voltage Control Supporting the WoC Concept}

The structural framework for transparency in the market for frequency and voltage control responds and fits that presented in Section 5. However, the content of the developed framework (Figure 6) is adapted to the peculiarities of architecture for frequency and voltage control and related market design. In the following, the key structural elements of the framework for transparency in market for frequency and voltage control are analyzed.

\subsection{Actors and Their Roles Improving Transparency in the Market for Frequency and Voltage Control}

In relation to a transparent market for frequency and voltage control, six roles are identified. These are data and information owners, providers, collectors, aggregators, publishers and users, as shown in Figure 7.

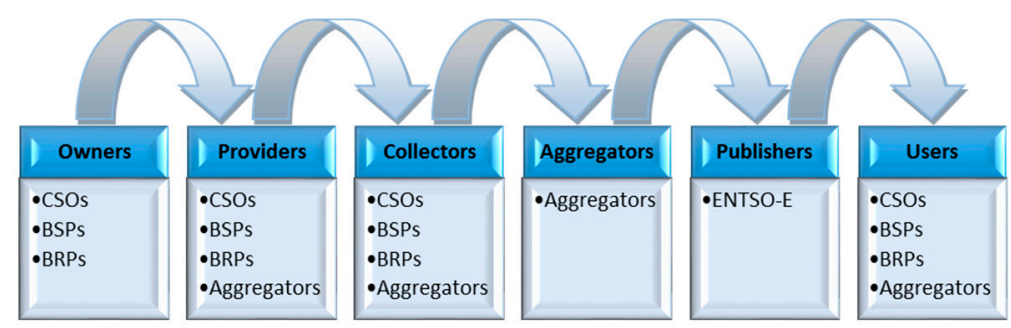

Figure 7. Actors and their roles in relation to data and information.

It can be seen that actors taking part in the market for frequency and voltage control are not limited to a single role. Moreover, actors in relation to data and information are prescribed to exercise a variety of roles.

The CSOs, who are the tie-line providers and the system imbalance calculators, represent an essential source of data and information at the WoC level. They collect, provide and use a considerable volume of data and information for the efficient system operation. In the market for frequency and voltage control, they take these roles to establish the demand curves for the UCs.

The BSPs, who are the providers for inertia capacity, inertia, balancing capacity, balancing energy and reactive power, managing electricity production and consumption units, and being located within the cell, are the primary data owners, and they provide the relevant data and information to the CSOs, when bidding on the market for frequency and voltage control and establishing the supply curves of the UCs. In addition, in order to develop efficient bidding strategies, they analyze market conditions and thus act both as users of data and information produced by the market for frequency and voltage control, and as collectors of other relevant data.

The BRPs, having an obligation to balance their positions thereby contributing to the balance of electricity system, are relevant data and information owners, providers to the CSO to calculate the system imbalance, and users of data and information of the market for frequency and voltage control when deciding methods on how to balance their positions. The BRPs are collectors, providers and 
users of data and the information required to exercise load and generation forecasting activity. In this respect, small-scale and large-scale BRPs interact with different actors and, therefore, take different roles as shown in Figure 8.

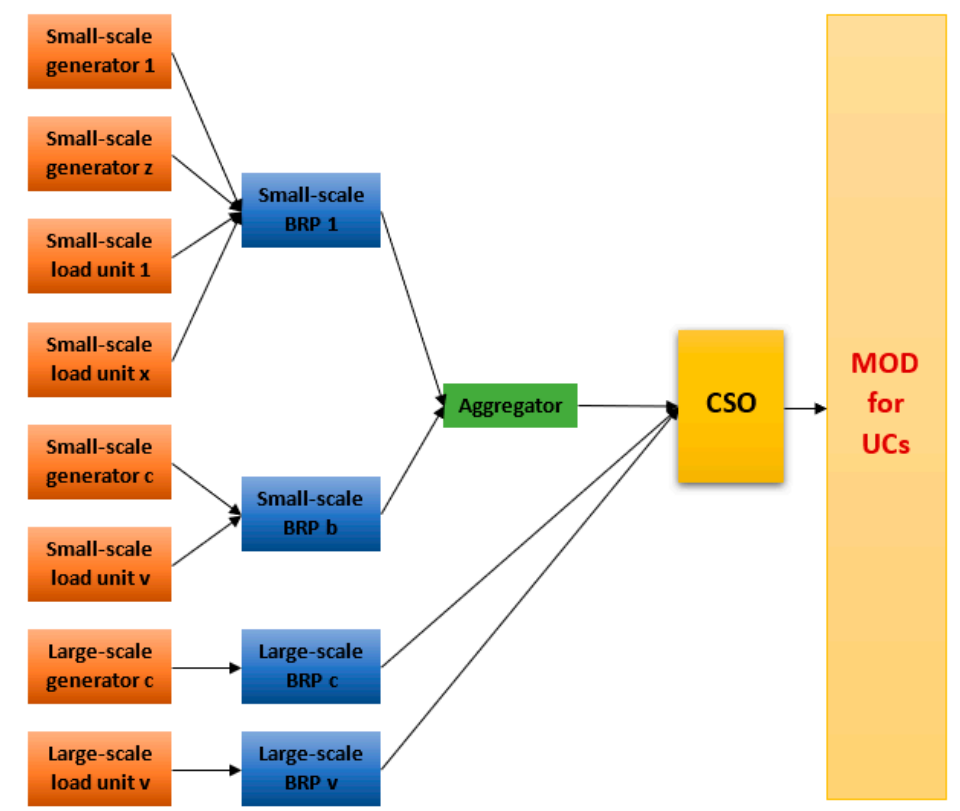

Figure 8. Interactions of actors in terms of data and information flows to exercise load and generation forecast activity [37].

It can be noted that large-scale BRPs are load and generation forecasters. Therefore, they collect data and information from large-scale generation units and large-scale loads and use data and information for that purpose. After making load and generation forecasts, they provide data and information to the CSOs for establishing the demand curve for UCs. Small-scale BRPs are collectors of data and information from small-scale generation units and small-scale loads, and providers of these data and information to the aggregator.

The aggregators, being load and generation forecasters, take the active role of data collectors from small-scale BRPs, users and aggregators of all data and information. After making load and generation forecasts, they take the role of providers of the relevant data to the CSOs.

The ENTSO-E takes the role of making the data and information available to the public through the information transparency platform. It is provided with the relevant data by the CSO.

\subsection{The Use of Data and Information}

The aforementioned roles exercised by the actors in the market for frequency and voltage control are performed to implement the following functions:

- MOC function of a specific UC. Within the MOC function, the BSPs provide inertia capacity, balancing capacity, inertia, balancing energy and reactive power bids (pairs of ask prices and volumes) and the CSO collects those bids. Therefore, the CSO establishes an initial Merit Order list, considering the eco-label of the BSPs, and the arranged volumes of the UC product (sequentially in price ascending order), which form the supply curve of that UC.

- MOD function of a specific UC. Within the MOD function, generation and load forecasts, volumes of scheduled production and consumption of all generators and loads, as well as operating constraints of the tie-line on which the UCs are to be deployed, are collected by the CSOs for establishing the demand curve of the UC. The MOD function is implemented through the interaction of supply and demand curves which results in setting the clearing price and volume of that UC product. 


\subsection{Minimum Data Requirements for the Implementation of Merit Order Collection (MOC) Function}

Within the MOC function, bidding is organized and an initial Merit Order list is established. The market actors are set in advance with minimum data requirements that are ask price and volume of the UC. In particular, the CSO requests pairs of ask prices and volumes of the UCs products for a particular market time unit from a variety of the BSPs. Responding to the CSO data requirements, the BSPs bid prices at which they agree to sell a certain volume of UCs products. The establishment of initial Merit Order list is complex since residential level bids (involving VPPs, DR technologies, EVs, PVs connected to distribution grid, etc.) are considered in addition to the widely accepted current practice.

Making the aforementioned process efficient and transparent, timing of bidding and clearing processes of UCs are determined (as shown earlier in Figure 5) and the method for ranking of bids is selected. Moreover, when RES, DER, EVs and storage technologies are used at a scale, the minimum data requirements for the MOC function is expanded to cope with the changes in electricity supply, including supply of UCs. In particular, the information regarding eco-label of the BSPs are requested because the CSO and market actors become responsible and, thus willing to pay for UCs products provided by RES, DER, EVs and storage technologies. Different data and information are required by the BSPs to decide on the ask price and volume of UCs products and participation in the MOC function on the whole as shown in Figure 9.
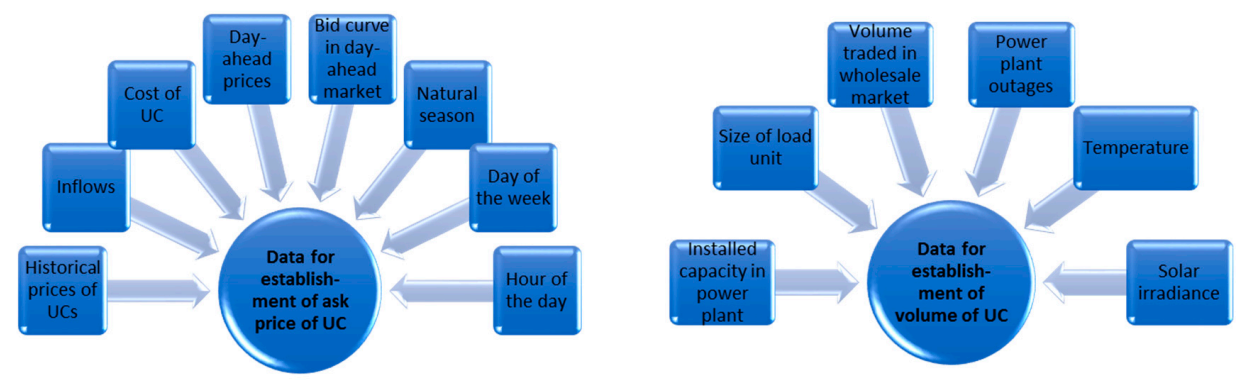

Figure 9. Secondary data requested for the establishment of initial Merit Order list.

With the aim of assisting the BSPs in taking the temporal rational economic decision such as bidding in the market for frequency and voltage control for the specific UC, the prices [13] of inertia capacity, inertia, balancing capacity, balancing energy and reactive power are important, since they disclose the possibilities of participation in the market and additional profit earning (mainly, the profit should be earned in day-ahead and intraday electricity markets in future). In agreement with the efficient market hypotheses [38] saying that all relevant information is reflected in prices and, therefore, they are consistent with fundamental factors, the price of UCs products is the key factor when deciding on the ask price of the UC product. In case the BSPs take informed intertemporal decisions (when to do maintenance, repair, upgrade of PP, entry into and exit from the market) [13], they should be supplied with historical prices. Therefore, current and historical prices are relevant and should be made available for the BSPs. Additional information about underlying processes of UC product price formation is valuable in case the missing data problem exists and, therefore, price forecast is necessary [13].

The volume offered by the BSPs for the UC product could be decided considering the installed generation capacities at all voltage levels, DR capacities capable to provide the UCs products, results of trading in wholesale electricity market and natural conditions. The latter become even more relevant under the condition that UCs products are provided both by traditional PPs and advanced technologies.

\subsection{Minimum Data Requirements for the Merit Order Decision (MOD) Function}

Within the MOD function, the final Merit Order list is established. For this purpose, as shown in Figure 10, the CSOs require the initial Merit Order lists of UCs, the data for the estimation of volume demanded for a specific $\mathrm{UC}$, and the information regarding constraints in the tie-line. 


\begin{tabular}{|c|c|}
\hline Initial Merit Order lists of UCs & - supply curves of UCs \\
\hline Generation and load forecasts & $\begin{array}{l}\text {-electricity consumption forecast by type of consumer } \\
\text {-electricity production forecast, including wind and solar }\end{array}$ \\
\hline Natural conditions & $\begin{array}{l}\text {-expected air temperature } \\
\text { - expected solar irradiance } \\
\text { •expected precipitation and water levels in reservoirs }\end{array}$ \\
\hline Electricity market data & $\begin{array}{l}\text {-actual volume of electricity traded in forward, day-ahead, intraday markets } \\
\text {-actual volume of inertia capacty, inertia, balancing capacity, balancing energy and } \\
\text { reactive poewer } \\
\text {-historical day-ahead/intraday/balancing electricity prices, prices for capacity }\end{array}$ \\
\hline Data about power plant outages & $\begin{array}{l}\text { - total power plant outages } \\
\text {-nuclear power plan outages } \\
\text {-virtual power plant outages } \\
\text { - RES power plant outages }\end{array}$ \\
\hline Data about tie-line outages & -tie-line outages in and between Cells \\
\hline EU-ETS market data & -prices of emission allowances \\
\hline RES electricity market data & $\begin{array}{l}\text {-support to electricity produced from RES } \\
\text {-historical wind electricity production volume } \\
\text {-historical solarelectricity production volume }\end{array}$ \\
\hline Special regulation & $\begin{array}{l}\text {-information about activation of bids in casual cases } \\
\text {-information about activation of bids in unusual cases }\end{array}$ \\
\hline Calendar effect & $\begin{array}{l}- \text { natural season } \\
- \text { day of the week } \\
\text {-hour of the day } \\
\text {-quater of the day }\end{array}$ \\
\hline Demand response data & $\begin{array}{l}\text {-incentive payments } \\
\text {-industrial and residential demand response constraints (loads) } \\
\text {-heat pump and energy storage constraints } \\
\text {-smart EV charging network infrastructure capabilities and use }\end{array}$ \\
\hline
\end{tabular}

Figure 10. Data requested for the establishment of final Merit Order list.

The establishment of the final Merit Order list is troublesome, since generation and load forecaster require a large set of data for the establishment of generation and load forecasts due to diversification of supply resources and variety of DR technologies. Indeed, the tie-line constraints at different network voltage levels are considered by the CSOs, and this also increases the complexity of the decision for the final Merit Order list.

\subsection{Placement of Data}

The data and information required for the MOC and the MOD making, as well as the data outgoing from the aforementioned functions are placed in the ENTSO-E Transparency Platform [39] which is the most ambitious electricity data platform developed within the European electricity transparency framework [18]. It is available in English to the public free of charge through the internet. Here, the ENTSO-E publishes all relevant data and information submitted by the data providers in accordance with the list of minimum data and information requirements set in [16]. Presently, the ENTSO-E Transparency Platform lags behind the data quality (completeness and consistency) and platform usability (navigation of website, data documentation and availability of download option) criteria [18]. Thus far, it suffers from missing data, reporting data and public documentation, narrow scope, reporting inaccuracy, inaccuracy in data definitions, outage data, overwriting forecasts, delays in data availability, automatic download, data documentation, user support, website navigation, displaying data availability issues [19]. Therefore, responding to them, improvements should be made in five key directions shown in Figure 11. 


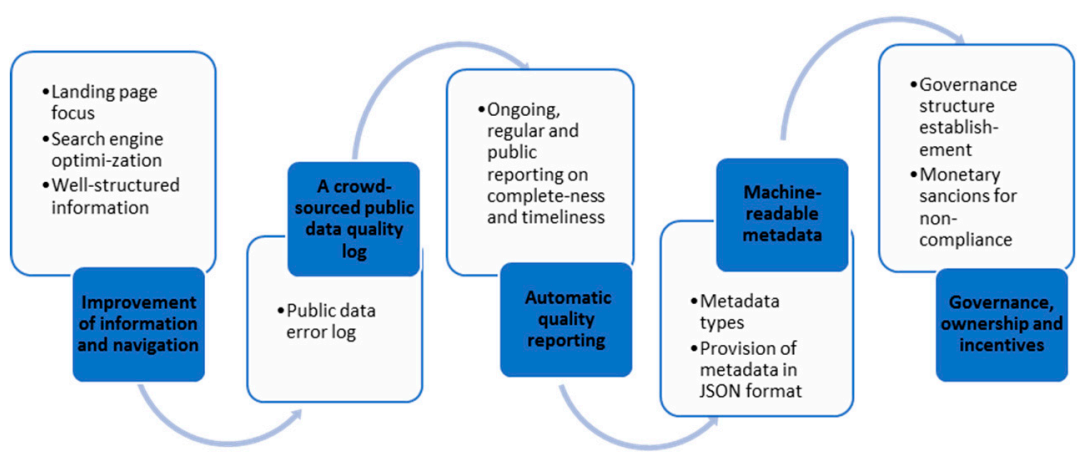

Figure 11. Suggestions for improvement of the European Network of Transmission System Operators for Electricity (ENTSO-E) Transparency Platform [19].

After these improvements are in place, it is a relevant measure of market transparency for the WoC concept.

\subsection{Data and Information Publication}

In order to achieve transparency in the market for frequency and voltage control, the ENTSO-E publishes the following information:

- Rules on the functioning of the market for frequency and voltage control, including description of exchange and peculiarities of auctioning, provision of UCs products and imbalance settlement (Figure 12);

- Aggregated data related to the trade in inertia capacity and balancing capacity (Table 1);

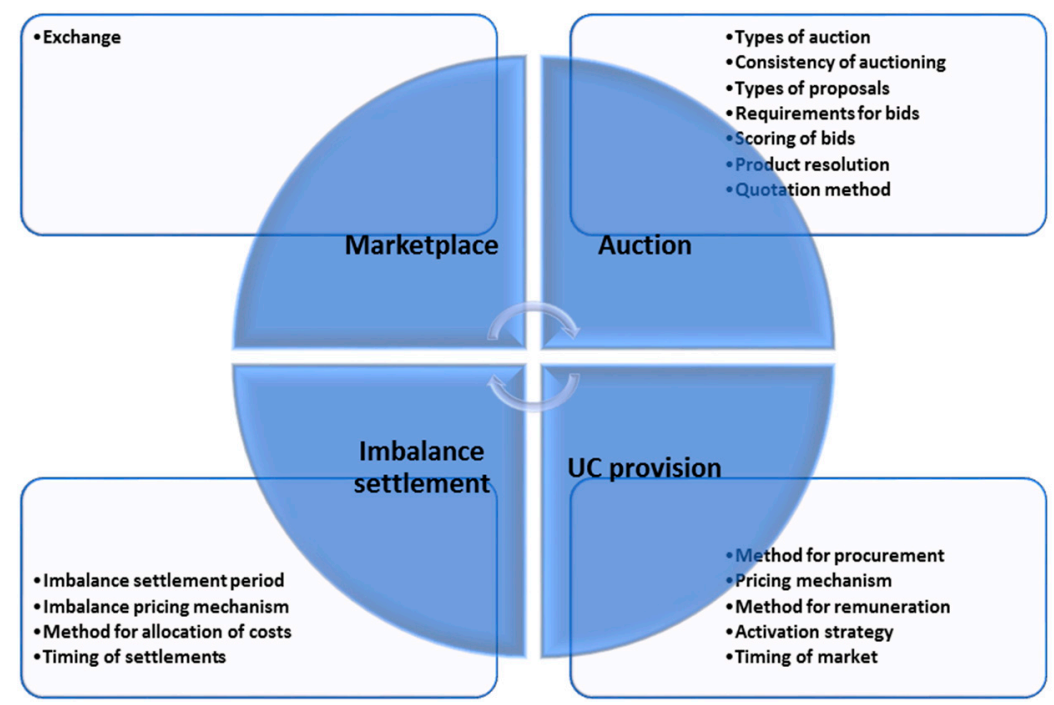

Figure 12. Information that should be published about market for frequency and voltage control.

In case market actors cross-cell trade in the BSC service, in addition to the data provided in Table 1, price (minimum and maximum) of bid volume of balancing capacity by the CSOs is published.

- $\quad$ Aggregated data related to the trade in inertia and balancing energy (Table 2);

In case market actors cross-cell trade in the BSC service, in addition, price (minimum and maximum) of bided volume of balancing energy by the CSOs is published.

- Aggregated data related to the trade in reactive power (Table 3). 
Table 1. Publication of aggregated data related to the trade in inertia capacity and balancing capacity.

\begin{tabular}{|c|c|c|c|c|c|c|c|c|c|c|}
\hline \multirow{2}{*}{$\begin{array}{l}\text { Market } \\
\text { Time Unit }\end{array}$} & \multirow{2}{*}{$\begin{array}{l}\text { Class of } \\
\text { Balancing } \\
\text { Product }\end{array}$} & \multirow{2}{*}{$\begin{array}{l}\text { Direction of } \\
\text { Balancing } \\
\text { Product }\end{array}$} & \multirow{2}{*}{ Type of BSP } & \multirow{2}{*}{$\begin{array}{l}\text { Contract } \\
\text { Type }\end{array}$} & \multirow[b]{2}{*}{ Cell } & \multirow{2}{*}{$\begin{array}{c}\text { Offered Volume of } \\
\text { Inertia Capacity or } \\
\text { Balancing Capacity, } \\
\text { MW*s, MW }^{*}\end{array}$} & \multicolumn{2}{|c|}{$\begin{array}{c}\text { Price of Offered Inertia } \\
\text { Capacity or Balancing Capacity }\end{array}$} & \multirow{2}{*}{$\begin{array}{l}\text { Clearing Price of } \\
\text { Inertia Capacity or } \\
\text { Balancing Capacity, } \\
\text { EUR/(MW*s), } \\
\text { EUR/MW }\end{array}$} & \multirow{2}{*}{$\begin{array}{c}\text { Clearing Volume } \\
\text { of Inertia Capacity } \\
\text { or Balancing } \\
\text { Capacity, MW*s, } \\
\text { MW }\end{array}$} \\
\hline & & & & & & & $\begin{array}{c}\text { Minimum, } \\
\text { EUR/(MW*s), } \\
\text { EUR/MW }\end{array}$ & $\begin{array}{c}\text { Maximum, } \\
\text { EUR/(MW*s), } \\
\text { EUR/MW }\end{array}$ & & \\
\hline 00:00-00:15 & BSC & Downward & Generation & $15 \mathrm{~min}$ & A & & & & & \\
\hline 00:15-00:30 & BRC & Upward & Load & $45 \mathrm{~min}$ & B & & & & & \\
\hline 00:30-00.45 & $\mathrm{aFCC}$ & & & $60 \mathrm{~min}$ & C & & & & & \\
\hline 00:45-01:00 & IRPC & & & & $\mathrm{D}$ & & & & & \\
\hline
\end{tabular}

Table 2. Publication of aggregated data related to the trade in inertia and balancing energy.

\begin{tabular}{|c|c|c|c|c|c|c|c|c|c|c|}
\hline \multirow{2}{*}{$\begin{array}{c}\text { Market } \\
\text { Time Unit }\end{array}$} & \multirow{2}{*}{$\begin{array}{c}\text { Class of } \\
\text { Balancing } \\
\text { Product }\end{array}$} & \multirow{2}{*}{$\begin{array}{l}\text { Direction of } \\
\text { Balancing } \\
\text { Product }\end{array}$} & \multirow{2}{*}{ Type of BSP } & \multirow{2}{*}{$\begin{array}{l}\text { Contract } \\
\text { Type }\end{array}$} & \multirow[b]{2}{*}{ Cell } & \multirow{2}{*}{$\begin{array}{c}\text { Offered Volume of } \\
\text { Balancing Energy } \\
\text { or Inertia, MWh or } \\
\text { kgm }^{2}\end{array}$} & \multicolumn{2}{|c|}{$\begin{array}{l}\text { Offered Price of Balancing } \\
\text { Energy or Inertia }\end{array}$} & \multirow{2}{*}{$\begin{array}{l}\text { Clearing Price of } \\
\text { Balancing Energy } \\
\text { or Inertia, } \\
\text { EUR/MWh or } \\
\text { EUR/kgm }{ }^{2}\end{array}$} & \multirow{2}{*}{$\begin{array}{l}\text { Clearing Volume } \\
\text { of Balancing } \\
\text { Energy or Inertia } \\
\text { MWh or kgm }\end{array}$} \\
\hline & & & & & & & $\begin{array}{l}\text { Minimum, } \\
\text { EUR/MWh or } \\
\text { EUR/kgm }^{2}\end{array}$ & $\begin{array}{c}\text { Maximum, } \\
\text { EUR/MWh or } \\
\text { EUR/kgm }{ }^{2}\end{array}$ & & \\
\hline 00:00-00:15 & BRC & Downward & Generation & $15 \mathrm{~min}$ & A & & & & & \\
\hline 00:15-00:30 & BSC & Upward & Load & $45 \mathrm{~min}$ & B & & & & & \\
\hline 00:30-00.45 & $\mathrm{aFCC}$ & & & $60 \mathrm{~min}$ & C & & & & & \\
\hline 00:45-01:00 & IRPC & & & & $\mathrm{D}$ & & & & & \\
\hline
\end{tabular}

Table 3. Publication of aggregated data related to the trade in reactive power.

\begin{tabular}{|c|c|c|c|c|c|c|c|c|c|}
\hline \multirow{2}{*}{$\begin{array}{l}\text { Market Time } \\
\text { Unit }\end{array}$} & \multirow{2}{*}{$\begin{array}{l}\text { Class of Voltage } \\
\text { Control Product }\end{array}$} & \multirow{2}{*}{$\begin{array}{l}\text { Type of Voltage } \\
\text { Control Product }\end{array}$} & \multirow{2}{*}{$\begin{array}{l}\text { Contract } \\
\text { Type }\end{array}$} & \multirow[b]{2}{*}{ Cell } & \multirow{2}{*}{$\begin{array}{c}\text { Offered } \\
\text { Volume of } \\
\text { Reactive } \\
\text { Power, VAr }\end{array}$} & \multicolumn{2}{|c|}{$\begin{array}{l}\text { Offered Price of } \\
\text { Reactive Power }\end{array}$} & \multirow{2}{*}{$\begin{array}{c}\text { Clearing Price of } \\
\text { Reactive Power, } \\
\text { EUR/VAr }\end{array}$} & \multirow{2}{*}{$\begin{array}{l}\text { Clearing } \\
\text { Volume of } \\
\text { Reactive } \\
\text { Power, VAr }\end{array}$} \\
\hline & & & & & & $\begin{array}{l}\text { Minimum, } \\
\text { EUR//VAr }\end{array}$ & $\begin{array}{l}\text { Maximum, } \\
\text { EUR/VAr }\end{array}$ & & \\
\hline 00:00-00:15 & PPVC & Inductive & $15 \mathrm{~min}$ & A & & & & & \\
\hline 00:15-00:30 & & Capacitive & $45 \mathrm{~min}$ & B & & & & & \\
\hline $00: 30-00.45$ & & & $60 \mathrm{~min}$ & $\mathrm{C}$ & & & & & \\
\hline 00:45-01:00 & & & & $\mathrm{D}$ & & & & & \\
\hline$:$ & & & & $:$ & & & & & \\
\hline
\end{tabular}


The data on the imbalance include imbalance prices subject to downward and upward regulation, and total imbalance volume in each cell per market time unit.

Since competitive market structure is selected, therefore, ability of the actors to manipulate in the market is little, thus, in agreement with [10], it is less important to publish individual data.

\section{Tailoring the Regulatory Frameworks of Market Transparency Supporting the WoC Concept}

The analysis of the European regulatory framework for wholesale electricity market transparency showed that relevant aspects of market transparency are addressed in legislation in detail by focusing on sensitive scope of market transparency. Therefore, the WoC concept respects the aforementioned regulatory rules as they are relevant for the related wholesale electricity market and market for frequency and voltage control functioning. In particular, it respects regulatory rules by setting the minimum market transparency requirements for actors, the boundaries of the IEM use, the dimensions of the wholesale electricity market transparency model, as well as the requirement for data and information submission and publication.

The WoC concept, respecting the state-of-the-art regulatory rules for market transparency, goes beyond them. Recognizing that market transparency is an important measure of a common market building, it proposes to integrate the supplemented list of the regulatory rules:

- Regulatory rules on disclosure of information regarding capacities, use and other attributes of intermittent RES, DER, EVs and storage technologies and VPP, connected to low, medium and high-voltage levels that are relevant to make decisions in the wholesale electricity market and market for frequency and voltage control.

- Regulatory rules for the provision of generation and load forecast information for the implementation of the MOD function by obliging large-scale BRPs and aggregators to take this responsibility in the cell.

- Regulatory rules for the process of intra-cell and inter-cell procurement of flexibilities via the auction-based exchange by employing a marginal pricing method for price setting and BSPs remuneration, based on short-term flexible, non-discriminating, transparent and competitive market principles.

- Regulatory rules for information disclosure to improve transparency in the market for frequency and voltage control. At least, the qualitative requirements for data and information should be set, the minimum data set and its availability for the MOC and the MOD making should be determined, the roles for the market actors regarding data and information ownership, provision, collection, aggregation and use should be established, the data and information placement should be proposed, and the data and information publication problem should be addressed.

- Regulatory rules for improving retail market transparency, since, due to technological improvements as well as their cost-efficiency and smart metering, the retail-level actors (directly or through the aggregation) take part in the wholesale electricity market and market for frequency and voltage control.

- Regulatory rules regarding disclosure of privacy-sensitive household attributes, as the residential sector through the aggregation will be a relevant actor of the wholesale electricity market and market for frequency and voltage control. In detail, they should respect the privacy preserving disclosure of information and data, and propose privacy-protecting measures.

- Regulatory rules strengthening the responsibility of actors for a transparent market development, by imposing actors with financial penalties for non-compliance with transparency requirements.

Moreover, the WoC concept proposes an approach such that dispersed regulatory rules on market transparency issues are consolidated into a single legal act. This allows avoiding duplication and repetition of regulatory rules, and improves performance of actors in relation to market transparency. Moreover, this consolidation creates a precondition to develop a well-structured and consistent layout of framework for market transparency covering different areas of regulation within a single document. 
Consolidation of regulatory rules on market transparency should be made in two directions, i.e., both general energy market transparency rules and electricity market-specific rules should be established.

\section{Conclusions}

This paper investigates the issue of transparency in the wholesale electricity market and market for frequency and voltage control within the WoC concept developed in the ELECTRA project to respond the challenges of future power systems (2030+), that will be supplied by high volumes of intermittent RES, DER, EVs and storage technologies. In detail, it analyzes the framework of market transparency for the $\mathrm{WoC}$ from the perspective of regulatory rules that impose minimum requirements for data and information for actors taking part in the wholesale electricity market and market for frequency and voltage control.

The detailed review of the European legislation on the framework for wholesale electricity market transparency shows that market transparency is a relevant issue in Europe, as it is comprehensively addressed through the directive [24] and several dispersed European regulations [16,30-32]. It is found that the wholesale electricity market transparency framework consists of a number of market transparency requirements set for actors participating in such a market, the IEM that improves the access to the network for cross-border exchanges in electricity, the multidimensional wholesale electricity market transparency model that prevents market abuse and fosters open and fair competition, and the framework of data and information submission and publication. The market transparency framework is well-developed-its actual, detailed, elements of market transparency are well-structured and described-as it includes relevant areas of market transparency that respond to challenges from present to short and medium terms. Therefore, the European-level provisions on market transparency should be respected by actors at least for the identified time period.

The detailed analysis of the $\mathrm{WoC}$ architecture for frequency and voltage control and the related market allows identifying the key functionalities (UCs) of this decentralized control paradigm, fixing the functions of the UCs based on which the market works, and recognizing the structure of the wholesale electricity market and the market for frequency and voltage control with the related design and peculiarities. In detail, the MOC and the MOD functions through which the market works are found to be constituent parts of the new architecture. Moreover, it is found that in order to ensure an efficient operation of the MOC and the MOD functions, the Scandinavian practice-based wholesale electricity market should be considered, and it should be supplemented by the market for frequency and voltage control. This latter should operate on competitive market principles, including the principle of transparency.

The results of the development of the framework for wholesale electricity market transparency supporting the WoC concept reveal that high-level European regulatory rules on market transparency could be integrated into the framework as they are universal and address the key issues and relevant scopes of market transparency. Specifically, the framework for wholesale electricity market transparency should take into account the responsibilities of actors in relation to market transparency, the IEM to enhance access to the network, transparency requirements to prevent market abuse and foster competition, and the requirements for data and information submission and publication. The framework goes beyond the established European regulatory rules. In the concrete, it obliges old and new actors to behave in a transparent way in the market and disclose data and information more frequently. Moreover, it updates the content of the regulatory rules in relation to information disclosure by integrating transparency requirements for VPPs, EVs, storage and DR technologies.

The results of development of the framework for transparency in the market for frequency and voltage control shows the key structural elements of that framework, including the actors and their roles, the minimum data set and its availability for the MOC and the MOD making, the data placement and the data and information publication. It is found that within this framework, the CSO, the BSPs, the BRPs, the aggregators and the ENTSO-E should meet transparency requirements when owning, providing, collecting, aggregating, publishing and using data and information. The prices of UCs 
products should be the most relevant data requested for the rational economic decision making and the implementation of the MOC function. However, subject to the missing data problem, the factors of UC product price formation should be taken into account. A set up of data requirements for the implementation of the MOD function should be wide, as the MOD function is established considering the generation and load forecasts, the actual volumes of consumption and generation provided by a variety of actors from the diversified supply resources and DR technologies, as well as the tie-line constraints. The transparency platform should be an important measure of market transparency. Here a predetermined set of data and information should be published publicly and on time.

The analysis on tailoring the frameworks of market transparency to the regulatory rules shows that the WoC concept should respect the state-of-the-art EU regulatory rules on market transparency, and the frameworks should be supplied with supplemented rules that should disclose the peculiarities of the WoC concept. Therefore, new regulatory rules should be established on: (1) disclosure of information in respect to attributes of intermittent RES, DER, EVs and storage technologies and VPPs; (2) provision of generation and load forecast information; (3) process of procurement of flexibilities; (4) retail market transparency; (5) disclosure of privacy-sensitive household attributes; and (6) disclosure of information on market for frequency and voltage control. Moreover, when tailoring the frameworks of market transparency to the regulatory rules, the approach of consolidation of regulatory rules is also a key point.

Author Contributions: V.B.- development of the concepts and frameworks of market design and transparency in market for system services under the WoC control architecture; analysis of market transparency related regulations. M.D.S. - development of the concepts related to the $\mathrm{WoC}$ and decentralized control architecture in future power system; analysis of the benefits of market transparency with reference to the electricity sector; analysis of necessary evolution of the regulatory framework to enable WoC development; G.G.-analysis of future European scenarios in terms of renewables penetration, electrification trends, and flexibility resources presence at distribution level; development of the concepts related to the WoC-based control architecture; I.O.--development of a set of the rules for future energy markets and functional specification for future market design for the balancing and voltage control services under WoC control architecture.

Funding: This research was funded by the FP7 IRP ELECTRA Researcher Exchange (REX) Programme, grant number 609687.

Conflicts of Interest: The authors declare no conflict of interest.

\section{References}

1. Martini, L.; Brunner, H.; Rodriguez, E.; Caerts, C.; Strasser, T.I.; Burt, G. Grid of the Future and the Need for a Decentralized Control Architecture: The ELECTRA Web-of-Cells Concept. In Proceedings of the 24th International Conference on Electricity Distribution, Glasgow, UK, 12-15 June 2017.

2. Marinelli, M.; Pertl, M.; Rezkalla, M.M.N.; Kosmecki, M.; Canevese, S.; Obushevs, A.; Morch, A.Z. The Pan-European Reference Grid Developed in the ELECTRA Project for Deriving Innovative Observability Concepts in the Web-of-Cells Framework. In Proceedings of the 51st International Universities Power Engineering Conference (UPEC) IEEE, Coimbra, Portugal, 6 September 2016.

3. Kariniotakis, G.; Martini, L.; Caerts, C.; Brunner, H.; Retière, N. Challenges, Innovative Architectures and Control Strategies for Future Networks: The Web-of-Cells, Fractal Grids and Other Concepts. In Proceedings of the 24th International Conference on Electricity Distribution, Glasgow, UK, 12-15 June 2017.

4. Martini, L.; Radaelli, L.; Brunner, H.; Caerts, C.; Morch, A.; Hanninen, S.; Tornelli, C. ELECTRA IRP Approach to Voltage and Frequency Control for Future Power Systems with High DER Penetration. In Proceedings of the 23th International Conference on Electricity Distribution, Lyon, France, 15-18 June 2015.

5. Bobinaite, V.; Obushevs, A.; Oleinikova, I.; Morch, A. Economically Efficient Design of Market for System Services under the Web-of-Cells Architecture. Energies 2017, 11, 729. [CrossRef]

6. Oleinikova, I.; Bobinaite, V.; Obushevs, A. Market Design Supporting the Web-of-Cells Control Architecture. In Proceedings of the 15th International Conference on the European Energy Market, EEM2018, Lodz, Poland, 27-29 June 2018.

7. Bessembinder, H.; Maxwell, W.; Venkataraman, K. Market Transparency, Liquidity, Externalities, and Institutional Trading Costs in Corporate Bonds. J. Financ. Econ. 2006, 82, 251-288. [CrossRef] 
8. Baziliauskas, A.; Sanderson, M.; Yatchew, A. Electricity Market Data Transparency. November 2011. Available online: https:/ /albertamsa.ca/uploads/pdf/Archive/2011/Market\%20Data\%20Transparency / CRA\%20Report\%20for\%20MSA\%2011-22\%202011.pdf (accessed on 6 December 2018).

9. Browny, D.P.; Eckertz, A.; Lin, J. Information and Transparency in Wholesale Electricity Markets: Evidence from Alberta. J. Regul. Econ. 2018, 54, 292-330. [CrossRef]

10. Hooper, L.; Twomey, P.; Newbery, D. Transparency and Confidentiality in Electricity Markets; Bureau of European and Eurasian Affairs: Washington, DC, USA, 2009.

11. Michetti, E. Transparency in the European Wholesale Energy Markets: Filling the Regulatory Gaps. POLICY Brief. Available online: http:/ / cadmus.eui.eu/bitstream/handle/1814/20781/PB_2011_03_online. pdf? sequence $=1$ (accessed on 11 December 2018).

12. Holmberg, P.; Wolak, F. Electricity Markets: Designing Auctions Where Suppliers Have Uncertain Costs. Cambridge Working Papers in Economics, Paper 1541. 2015. Available online: https:/ / www.repository.cam.ac. uk/bitstream/handle/1810/255325/cwpe1541.pdf?sequence=1\&isAllowed=y (accessed on 15 September 2018).

13. Von der Fehr, N. Transparency in Electricity Markets. Memorandum 2013. 13/2013. Department of Economics, University of Oslo. Available online: https://www.sv.uio.no/econ/english/research/ unpublished-works/working-papers/pdf-files/2013/memo-13-2013.pdf (accessed on 18 November 2018).

14. European Regulators Group for Electricity \& Gas. ERGEG Draft Comitology Guidelines on Fundamental Electricity Data Transparency Initial Impact Assessment. 2010. Available online: https:/ /www.ceer.eu/documents/104400/ 3749189/E10-ENM-05-01_FEDT+IIA_8-Sept-2010.pdf/8b037005-4c1d-93b2-f7ba-297093a66a1b?version=1.0 (accessed on 30 September 2018).

15. Yang, Y.; Bao, M.; Ding, Y.; Song, Y.; Lin, Z.; Shao, C. Review of Information Disclosure in Different Electricity Markets. Energies 2018, 11, 3424. [CrossRef]

16. European Parliament and Council. Regulation No 543/2013 on Submission and Publication of Data in Electricity Markets. 14 June 2013. Available online: http:/ / eur-lex.europa.eu/LexUriServ/LexUriServ.do? uri=OJ:L:2013:163:0001:0012:EN:PDF (accessed on 30 September 2018).

17. Chen, W.; Zhou, K.; Yang, S.; Wu, C. Data quality of electricity consumption data in a smart grid environment. Renew. Sustain. Energy Rev. 2017, 75, 98-105. [CrossRef]

18. Hirth, L.; Mühlenpfordt, J.; Bulkeley, M. The ENTSO-E Transparency Platform-A review of Europe's most ambitious electricity data platform. Appl. Energy 2018, 225, 1054-1067. [CrossRef]

19. Deloitte. A Review of the ENTSO-E Transparency Platform. 2017. Available online: https://ec.europa.eu/ energy/sites/ener/files/documents/review_of_the_entso_e_plattform.pdf (accessed on 27 November 2018).

20. Wilcox, T.; Jin, N.; Flach, P.; Thumim, J. A Big Data platform for smart meter data analytics. Comput. Ind. 2019, 105, 250-259. [CrossRef]

21. Wiese, F.; Schlecht, I.; Bunke, W.-D.; Gerbaulet, C.; Schill, W.-P. Open Power System Data-Frictionless data for electricity system modelling. Appl. Energy 2019, 236, 401-409. [CrossRef]

22. Aasen, M.; Westskog, H.; Wilhite, H.; Lindberg, M. The EU electricity disclosure from the business perspective-A study from Norway. Energy Policy 2010, 38, 7921-7928. [CrossRef]

23. Markard, J.; Holt, E. Disclosure of electricity products-Lessons from consumer research as guidance for energy policy. Energy Policy 2003, 31, 1459-1474. [CrossRef]

24. European Parliament and Council. Directive 2009/72/EC on Common Rules for the Internal Market in Electricity. 13 July 2009. Available online: http:/ / eur-lex.europa.eu/legal-content/EN/ALL/?uri=celex\% 3A32009L0072 (accessed on 10 September 2018).

25. Bae, H.; Yu, S. Information and coercive regulation: The impact of fuel mix information disclosure on states adoption of renewable energy policy. Energy Policy 2018, 117, 151-159. [CrossRef]

26. Rubio, J.; Alcaraz, C.; Lopez, J. Recommender system for privacy-preserving solutions in smart metering. Pervasive Mob. Comput. 2017, 41, 205-218. [CrossRef]

27. Nakamura, Y.; Harada, K.; Nishi, H. A privacy-preserving sharing method of electricity usage using self-organizing map. ICT Express 2018, 4, 24-29. [CrossRef]

28. Mashima, D.; Serikova, A.; Cheng, Y.; Chen, B. Towards quantitative evaluation of privacy protection schemes for electricity usage data sharing. ICT Express 2018, 4, 35-41. [CrossRef]

29. Dimitriou, T.; Giannetsos, T.; Chen, L. REWARDS: Privacy-preserving rewarding and incentive schemes for the smart electricity grid and other loyalty systems. Comput. Commun. 2019, 137, 1-14. [CrossRef] 
30. European Parliament and Council. Regulation No 714/2009 on Conditions for Access to the Network for Cross-Border Exchanges in Electricity. 13 July 2009. Available online: http:/ / eur-lex.europa.eu/legalcontent/EN/TXT/?uri=CELEX:32009R0714 (accessed on 15 September 2018).

31. European Parliament and Council. Regulation No 713/2019 on the Establishment of the Agency for Cooperation of Energy Regulators. Available online: http:/ / eur-lex.europa.eu/legal-content/EN/ALL/ ?uri=CELEX\%3A32009R0713 (accessed on 20 September 2018).

32. European Parliament and Council. Regulation No 1227/2011 on Wholesale Energy Market Integrity and Transparency. 25 October 2011. Available online: http:/ / eur-lex.europa.eu/legal-content/EN/ALL/?uri= CELEX\%3A32011R1227 (accessed on 25 September 2018).

33. Agency for the Cooperation of Energy Regulators. REMIT: Organization within the Agency. Available online: https:/ / acer.europa.eu/en/remit/Pages/default.aspx (accessed on 25 September 2018).

34. Swora, M.; Kamiński, J. Liquidity and Transparency of the Wholesale Electricity Market: The Duty to Trade on a Power Exchange. 2016. Available online: https:/ / erranet.org/wp-content/uploads/2016/03/Swora-Kaminski_ Liquidity-and-Transparency-of-the-Wholesale-Electricity-Market.pdf (accessed on 16 December 2018).

35. Bobinaite, V.; Di Somma, M.; Graditi, G.; Oleinikova, I. Market Transparency for the Architecture of Frequency and Voltage Control under the Web-of-Cells Power Grid Structure. In Proceedings of the IEEE 18th International Conference on Environment and Electrical Engineering and 2nd Industrial and Commercial Power Systems Europe-EEEIC (EEEIC/I\&CPS Europe), Palermo, Italy, 12-15 June 2018.

36. Oleinikova, I.; Bobinaite, V.; Obushevs, A.; Grande, O.; Rikos, E.; Esterl, T.; Rodriguez, E.; Merino, J.; Moneta, D.; Evens, C.; et al. Deliverable 3.2 "Market Design Supporting the Web-of-Cells Control Architecture" of WP3 "Scenarios and Case Studies for Future Power Systems" of ELECTRA Project. 2018. Available online: http:/ / www.electrairp.eu/index.php?option=com_content\&view=category\&id= 63\&Itemid=154 (accessed on 10 September 2018).

37. Di Somma, M.; Valenti, M.; Ciavarella, R.; Graditi, G.; Merino, J.; Riano, S.; Hawker, G.; Carlini, C.; Bobinaite, V.; Cornez, L.; et al. Deliverable 3.3 “Analysis of Necessary Evolution of the Regulatory Framework to Enable the Web-of-Cells Development" of WP 3 "Scenarios and Case Studies for Future Power Systems" of ELECTRA Project. 2018. Available online: http:/ / www.electrairp.eu/index.php?option=com_content\& view $=$ category\&id=63\&Itemid=154 (accessed on 10 September 2018).

38. Beechey, M.; Gruen, D.; Vickery, J. The Efficient Market Hypothesis: A Survey. Research Discussion Paper; 2000. Available online: https:/ / www.rba.gov.au/publications/rdp/2000/pdf/rdp2000-01.pdf (accessed on 5 December 2018).

39. ENTSO-E Transparency Platform. Available online: https://transparency.entsoe.eu/ (accessed on 6 November 2018).

(C) 2019 by the authors. Licensee MDPI, Basel, Switzerland. This article is an open access article distributed under the terms and conditions of the Creative Commons Attribution (CC BY) license (http:/ / creativecommons.org/licenses/by/4.0/). 